\title{
Disrupted Calcium Signaling in Animal Models of Human Spinocerebellar Ataxia (SCA)
}

\author{
Francesca Prestori ${ }^{1, *}$, Francesco Moccia ${ }^{2}{ }^{-1}$ and Egidio D'Angelo ${ }^{1,3}$ \\ 1 Department of Brain and Behavioral Sciences, University of Pavia, 27100 Pavia, Italy; dangelo@unipv.it \\ 2 Department of Biology and Biotechnology "Lazzaro Spallanzani", University of Pavia, 27100 Pavia, Italy; \\ francesco.moccia@unipv.it \\ 3 IRCCS Mondino Foundation, 27100 Pavia, Italy \\ * Correspondence: francesca.prestori@unipv.it
}

Received: 29 November 2019; Accepted: 24 December 2019; Published: 27 December 2019

\begin{abstract}
Spinocerebellar ataxias (SCAs) constitute a heterogeneous group of more than 40 autosomal-dominant genetic and neurodegenerative diseases characterized by loss of balance and motor coordination due to dysfunction of the cerebellum and its efferent connections. Despite a well-described clinical and pathological phenotype, the molecular and cellular events that underlie neurodegeneration are still poorly undaerstood. Emerging research suggests that mutations in SCA genes cause disruptions in multiple cellular pathways but the characteristic SCA pathogenesis does not begin until calcium signaling pathways are disrupted in cerebellar Purkinje cells. $\mathrm{Ca}^{2+}$ signaling in Purkinje cells is important for normal cellular function as these neurons express a variety of $\mathrm{Ca}^{2+}$ channels, $\mathrm{Ca}^{2+}$-dependent kinases and phosphatases, and $\mathrm{Ca}^{2+}$-binding proteins to tightly maintain $\mathrm{Ca}^{2+}$ homeostasis and regulate physiological $\mathrm{Ca}^{2+}$-dependent processes. Abnormal $\mathrm{Ca}^{2+}$ levels can activate toxic cascades leading to characteristic death of Purkinje cells, cerebellar atrophy, and ataxia that occur in many SCAs. The output of the cerebellar cortex is conveyed to the deep cerebellar nuclei (DCN) by Purkinje cells via inhibitory signals; thus, Purkinje cell dysfunction or degeneration would partially or completely impair the cerebellar output in SCAs. In the absence of the inhibitory signal emanating from Purkinje cells, DCN will become more excitable, thereby affecting the motor areas receiving DCN input and resulting in uncoordinated movements. An outstanding advantage in studying the pathogenesis of SCAs is represented by the availability of a large number of animal models which mimic the phenotype observed in humans. By mainly focusing on mouse models displaying mutations or deletions in genes which encode for $\mathrm{Ca}^{2+}$ signaling-related proteins, in this review we will discuss the several pathogenic mechanisms related to deranged $\mathrm{Ca}^{2+}$ homeostasis that leads to significant Purkinje cell degeneration and dysfunction.
\end{abstract}

Keywords: spinocerebellar ataxias; Purkinje cells; $\mathrm{Ca}^{2+}$ signaling

\section{Introduction}

The cerebellum, the second largest area exceeded only by the cerebral cortex, contains more neurons than the rest of the brain. For most of the 20th century, it has long been thought that the cerebellum was involved in motor learning and coordination [1,2]. More recently, it has been recognized to play a role in cognitive and emotional processes [3]. Thus, cerebellar dysfunctions can cause motor and/or non-motor deficits. Following lesions confined to cerebellum, Schmahmann and Sherman first described a novel clinical condition characterized by an impairment of (1) executive functions, (2) spatial cognition, and (3) language [4]. This constellation of symptoms, known in humans as cerebellar cognitive-affective syndrome (CCAS), was ascribed to the functional disruption of cerebellar connections to the association cortices and limbic system [4]. On the other hand, lesions to the cerebellum can cause abnormal and 
uncoordinated body movements, particularly of the gait (ataxia), tremor and loss of muscle tone $[5,6]$. There can be a myriad of causes for cerebellar damage, including cerebellar agenesis, dysplasia and hypoplasia, cerebellar stroke, tumors, inflammation, trauma, viral infections, toxin exposure, and neurodegenerative diseases, such as hereditary ataxias [7]. The hereditary ataxias are a group of genetically and clinically defined neurological disorders phenotypically characterized by gait ataxia, often accompanied by lack of coordination of hands, speech, and eye movements. Furthermore, atrophy of the cerebellum has frequently been detected [8,9]. Hereditary ataxia can be subdivided by mode of inheritance (i.e., autosomal dominant, autosomal recessive, $\mathrm{X}$-linked, and mitochondrial), the mutated gene or chromosomal locus. Currently, more than 40 autosomal dominant types, named spinocerebellar ataxia (SCA) based upon the temporal order of discovery of the defective gene, are known, although the number is raising (Table 1) [10-12].

Table 1. SCA: Spinocerebellar ataxias.

\begin{tabular}{|c|c|c|c|c|c|}
\hline Location & SCA & $\begin{array}{l}\text { OMIM } \\
\text { Number }\end{array}$ & $\begin{array}{l}\text { Distinguishing Clinical } \\
\text { Manifestations }\end{array}$ & Gene & $\begin{array}{l}\text { Type of } \\
\text { Mutation }\end{array}$ \\
\hline $6 \mathrm{p} 22.3$ & SCA1 & 164400 & $\begin{array}{l}\text { Pyramidal signs, peripheral } \\
\text { neuropathy, and ophthalmoparesis }\end{array}$ & ATXN1 & $(\mathrm{CAG}) \mathrm{n}$ \\
\hline $12 \mathrm{q} 24.12$ & SCA2 & 183090 & $\begin{array}{l}\text { Hyporeflexia, tremor and slow eye } \\
\text { movements }\end{array}$ & ATXN2 & $(\mathrm{CAG}) \mathrm{n}$ \\
\hline $14 q 32.12$ & SCA3 & 109150 & $\begin{array}{l}\text { Motor neuron involvement and } \\
\text { Parkinsonian features }\end{array}$ & ATXN3 & $(\mathrm{CAG}) \mathrm{n}$ \\
\hline $16 q 22.1$ & SCA4 & 600223 & Sensory peripheral neuropathy & Unknown & Unknown \\
\hline $11 \mathrm{q} 13.2$ & SCA5 & 600224 & $\begin{array}{l}\text { Early onset and very slow disease } \\
\text { progression. }\end{array}$ & SPTBN2 & Point mutations \\
\hline 19 p13.13 & SCA6 & 183086 & $\begin{array}{l}\text { Late-onset, very slow disease } \\
\text { progression. and nystagmus. }\end{array}$ & CACNA1A & (CAG)n \\
\hline $3 p 14.1$ & SCA7 & 164500 & Visual loss & ATXN7 & (CAG)n \\
\hline $13 q 21$ & SCA8 & 608768 & $\begin{array}{l}\text { Cognitive dysfunction, pyramidal } \\
\text { and sensory signs }\end{array}$ & ATXN8 & $(\mathrm{CTG} * \mathrm{CAG}) \mathrm{n}$ \\
\hline 22q13.31 & SCA10 & 603516 & Occasional epilepsy & ATXN10 & (ATTCT)n \\
\hline $15 q 15.2$ & SCA11 & 604432 & Pyramidal signs. & TTBK2 & Point mutations \\
\hline $5 q 32$ & SCA12 & 604326 & $\begin{array}{c}\text { Tremor, Parkinsonian features and } \\
\text { dementia }\end{array}$ & $P P P 2 R 2 B$ & (CAG)n \\
\hline $19 q 13.33$ & SCA13 & 605259 & $\begin{array}{c}\text { Delayed motor and cognitive } \\
\text { development }\end{array}$ & KCNC3 & Point mutations \\
\hline $19 \mathrm{q} 13.42$ & SCA14 & 605361 & Dystonia and myoclonus. & PRKCG & Point mutations \\
\hline $3 p 26.1$ & SCA15/16 & 606658 & Tremor and cognitive impairment. & ITPR1 & Point mutations \\
\hline $6 \mathrm{q} 27$ & SCA17 & 607136 & Dementia and Parkinsonian features & TBP & $(\mathrm{CAG}) \mathrm{n}$ \\
\hline $7 q 22-q 32$ & SCA18 & 607458 & Sensory and motor neuropathy & IFRD1 & Point mutations \\
\hline $1 \mathrm{p} 13.2$ & SCA19/22 & 607346 & $\begin{array}{c}\text { Cognitive impairment and } \\
\text { myoclonus }\end{array}$ & KCND3 & Point mutations \\
\hline $11 \mathrm{q} 12$ & SCA20 & 608687 & Cerebellar dysarthria & Unknown & $\begin{array}{l}\text { Genomic } \\
\text { duplication }\end{array}$ \\
\hline $1 \mathrm{p} 36.33$ & SCA21 & 607454 & $\begin{array}{l}\text { Mild cognitive impairment, and } \\
\text { Parkinsonian features }\end{array}$ & TMEM240 & Unknown \\
\hline $20 \mathrm{p} 13$ & SCA23 & 610245 & Pyramidal signs & PDYN & Point mutations \\
\hline 2p21-p13 & SCA25 & 608703 & Peripheral neuropathy, & Unknown & Unknown \\
\hline 19 p13.3 & SCA26 & 609306 & Eye movement abnormalities. & EEF2 & Point mutations \\
\hline $13 q 33.1$ & SCA27 & 609307 & Tremor and dystonia & FGF14 & Point mutations \\
\hline
\end{tabular}


Table 1. Cont.

\begin{tabular}{|c|c|c|c|c|c|}
\hline Location & SCA & $\begin{array}{l}\text { OMIM } \\
\text { Number }\end{array}$ & $\begin{array}{l}\text { Distinguishing Clinical } \\
\text { Manifestations }\end{array}$ & Gene & $\begin{array}{c}\text { Type of } \\
\text { Mutation }\end{array}$ \\
\hline 18p11.21 & SCA28 & 610246 & Spastic ataxia & AFG3L2 & Point mutations \\
\hline 3 p26.1 & SCA29 & 117360 & Intellectual disability. & ITPR1 & Point mutations \\
\hline $4 q 34.3-q 35.1$ & SCA30 & 613371 & Pure ataxia. & ODZ3 & Unknown \\
\hline $16 \mathrm{q} 21$ & SCA31 & 117210 & Abnormal sensation & BEAN1 & (TGGAA)n \\
\hline $6 q 14.1$ & SCA34 & 133190 & Hyperkeratosis & ELOVL4 & Unknown \\
\hline 20p13 & SCA35 & 613908 & $\begin{array}{c}\text { Ocular dysmetria, tremor and } \\
\text { hyperreflexia }\end{array}$ & TGM6 & Point mutations \\
\hline $20 \mathrm{p} 13$ & SCA36 & 614153 & Motor neuron involvement & NOP56 & (GGCCTG)n \\
\hline $1 \mathrm{p} 32.2$ & SCA37 & 615945 & Altered vertical eye movements. & $D A B 1$ & (GGCCTG)n \\
\hline $6 \mathrm{p} 12.1$ & SCA38 & 615957 & Nystagmus and dysarthria & ELOVL5 & Point mutations \\
\hline $14 q 32.11-q 32.12$ & SCA40 & 616053 & Ocular dysmetria and tremor & CCDC $88 \mathrm{C}$ & Point mutations \\
\hline $4 \mathrm{q} 27$ & SCA41 & 616410 & Imbalance and loss of coordination & TRPC3 & Point mutations \\
\hline $17 q 21.33$ & SCA42 & 618087 & $\begin{array}{c}\text { Gait instability, dysarthria and } \\
\text { nystagmus }\end{array}$ & CACNA1G & Point mutations \\
\hline $3 q 25.2$ & SCA43 & 617018 & Peripheral neuropathy & $M M E$ & Point mutations \\
\hline $6 q 24.3$ & SCA44 & 617691 & $\begin{array}{c}\text { Dysarthria, dysphagia and } \\
\text { dysmetria }\end{array}$ & GRM1 & Point mutations \\
\hline $5 q 33.1$ & SCA45 & 617769 & Nystagmus, and dysarthria. & FAT2 & Point mutations \\
\hline $19 q 13.2$ & SCA46 & 617770 & Sensory ataxic neuropathy & PLD3 & Point mutations \\
\hline $12 \mathrm{p} 13.31$ & DRLPA & 125370 & $\begin{array}{l}\text { Involuntary movements, mental } \\
\text { and emotional problems }\end{array}$ & ATN1 & $(\mathrm{CAG}) \mathrm{n}$ \\
\hline $4 q 22.1-q 22.2$ & \multicolumn{2}{|c|}{$\begin{array}{l}\text { GRID2-related } \\
\text { spinocerebellar616204 } \\
\text { ataxia }\end{array}$} & $\begin{array}{l}\text { Motor, speech and cognitive delay } \\
\text { and eye movement abnormalities }\end{array}$ & $\begin{array}{l}\text { GRID2Rarely } \\
\text { AD inheritance }\end{array}$ & Point mutations \\
\hline
\end{tabular}

The most common forms of SCAs are caused by an abnormal expansion of the CAG (or CGT)-repeat sequence that leads to lengthening of polyglutamine (polyQ) tract in appropriate proteins [13-16]. In contrast, other forms of SCAs are characterized by conventional point mutations, including insertions and deletions [17-19]. Disruption of intracellular calcium $\left(\mathrm{Ca}^{2+}\right)$ signaling in Purkinje cells is thought to be a key mechanism in the pathogenesis of SCAs [12,20-22]. $\mathrm{Ca}^{2+}$ signaling in Purkinje cells is important for normal cellular function as these neurons express a variety of $\mathrm{Ca}^{2+}$ channels, $\mathrm{Ca}^{2+}$-dependent kinases and phosphatases, and $\mathrm{Ca}^{2+}$-binding proteins to tightly maintain $\mathrm{Ca}^{2+}$ homeostasis and regulate physiological $\mathrm{Ca}^{2+}$-dependent processes. Abnormal $\mathrm{Ca}^{2+}$ levels can activate toxic cascades leading to cell death. The output of the cerebellar cortex is conveyed to the deep cerebellar nuclei (DCN) by Purkinje cells via inhibitory signals; thus, Purkinje cell dysfunction or degeneration would partially or completely impair the cerebellar output in SCAs. In the absence of the inhibitory signal emanating from Purkinje cells, DCN will become more excitable, thereby affecting the motor areas receiving DCN input and resulting in uncoordinated movements [22-24]. An outstanding advantage in studying the pathogenesis of SCAs is represented by the availability of a large number of animal models which mimic the phenotype observed in humans $[6,25,26]$. By mainly focusing on mouse models displaying mutations or deletions in genes which encode for $\mathrm{Ca}^{2+}$ signaling-related proteins, in this review we will discuss the hypothesis that the pathogenesis of diverse SCAs is related to deranged $\mathrm{Ca}^{2+}$ homeostasis that leads to significant Purkinje cell degeneration and dysfunction. 


\section{Mutations in the CACNA1A Gene}

Different mutations in the $C A C N A 1 A$ gene, encoding for the pore-forming, voltage-sensing $\alpha 1 \mathrm{~A}$-subunit of voltage-dependent $\mathrm{Ca}^{2+} \mathrm{Cav} 2.1$ type channels (P/Q-type), are known to result in neurological disorders, such as episodic ataxia type 2 (EA2), familial hemiplegic migraine type 1 (FHM1) and SCA type 6 (SCA6; Table 1) [27-29]. Each disorder is associated with different mutations in the CACNA1A gene that have differential effects on Cav2.1 function and, therefore, either decrease or increase neuronal $\mathrm{Ca}^{2+}$ influx. SCA6 is associated with small CAG repeat expansions expressed as a polyglutamine (poliQ) sequence at protein level [28]. Voltage-dependent $\mathrm{Ca}^{2+}$ channels (VDCCs) mediate $\mathrm{Ca}^{2+}$ influx into neurons in response to membrane depolarization, thereby modulating cellular excitability and triggering a variety of $\mathrm{Ca}^{2+}$-dependent cellular processes, such as neurotransmitter release, synaptic plasticity, gene transcription, cell division and cell death [30,31]. P/Q-type VDCCs are highly expressed in the cerebellum, in particular in Purkinje cells where they account for more than $90 \%$ of $\mathrm{Ca}^{2+}$ currents [32-35]. P/Q-type channels play key roles in regulating spike firing properties and contributing to $\mathrm{Ca}^{2+}$ transient/complex spikes that result from climbing fiber activity [36]. Moreover, they regulate heterosynaptic competition between climbing fibers and parallel fibers and also drive homosynaptic competition among multiple climbing fibers [37]. In contrast to human CACNA1A dominant mutations, the first animal model to be characterized showed predominantly recessive mutation in the CACNA1A gene (tottering mice) $[38,39]$. The tottering $(t g)$ mice display mildly ataxic behavior during locomotion [40-42]. In $t g$ Purkinje cells, the P/Q-type current density is decreased by $\sim 40 \%$ [43] and spike firing patterns show enhanced irregularities with periods of pauses and bursts [41]. Consistent with a reduced functional role of P/Q-type channels, parallel fiber-Purkinje cell synapses are impaired in $t g$ mutants [44]. Additionally, electron microscopic and Golgi-staining procedures have revealed shrunken Purkinje cells with a reduced size in the soma, abnormal Purkinje cell connectivity and diffuse axonal swellings [45-47]. Two additional recessive $t g$ mutations have been identified showing different but overlapping features (leaner and rolling Nagoya mice). As opposed to $t g$, leaner $\left(\mathrm{tg}^{\mathrm{la}}\right)$ and rolling Nagoya $\left(\mathrm{tg}^{\mathrm{rol}}\right)$ mice are severely ataxic [39,48,49]. In addition to causing a reduction in $\mathrm{P} / \mathrm{Q}$-type current density by $\sim 60 \%$, the $t g^{l a}$ mutation affects $\mathrm{Ca}^{2+}$ channel gating kinetics [43]. In detail, $\mathrm{Ca}^{2+}$ channel currents in $t g^{l a}$ Purkinje cells show a distinct change in the voltage dependence of activation and inactivation. Furthermore, these mice exhibit Purkinje cell degeneration whose parasagittal striped pattern is similar to the pattern of zebrin expression [39,50]. Likewise, electrophysiological studies have demonstrated that also the $\mathrm{tg}^{\text {rol }}$ mutation in Purkinje cells results in the reduced voltage sensitivity (i.e mutated channels are less sensitive to voltage stimuli) and diminished activity of $\mathrm{P} / \mathrm{Q}$-type channels $(\sim 40 \%)$ [51,52]. Overall, morphological investigations have revealed characteristic synaptic alteration between parallel fiber varicosity and Purkinje cell dendritic spines in all the three mutant mouse models of SCA. Multiple Purkinje cell dendritic spines synapse with single parallel fiber varicosity [47]. A recently described ataxic model in rats (GRY; groggy) is also featured by a recessive mutation [53]. The phenotype of the GRY rat resembles that of the $t g$ mouse rather than that of the other two mutant mice. In 2007, however, Xie and colleagues reported the first dominant ataxic mouse model of CACNA1A mutation, called Wobbly $(w b)$ on the basis of its peculiar gait [54]. Heterozygotes show severe ataxia and reduced locomotor activity with associated degeneration of Purkinje cells $[54,55]$. Purkinje cells display altered passive and active membrane properties and an altered synaptic excitation/inhibition balance in $w b$ mice. Specifically, $w b$ Purkinje cells are less excitable showing increased resting membrane potential and action potential threshold. Parallel fiber stimulation fails to evoke excitatory synaptic currents in more than $50 \%$ of Purkinje cells, while evoked synaptic inhibition is shown to be stronger [55]. Later, another dominant mutation, known as Tg-5J, in CACNA1A gene, resembling the wobby and many human mutations, was described by Miki and coworkers [56]. Heterozygotes $\mathrm{Tg}$-5J mice are extremely ataxic and homozygotes rarely survive. The Tg-5J mutation determines a negative shift in the P/Q-type channel activation curve despite of no significant changes in the $\mathrm{Ca}^{2+}$ current density [56]. Moreover, the dendritic arbor is significantly reduced in complexity and overall mass in Tg-5J Purkinje cells [56]. Since SCA6 share 
features in common with other polyglutamine (poliQ) diseases, it is reasonable to expect that the poliQ expansions would affect the P/Q-type channel function. Different studies, performed on several lines of knockin (KI) mice carrying expanded or hyperexpanded CAG repeat tracts in the CACNA1A gene, have achieved highly variable, often conflicting results. Matsuyama and colleagues showed that a P/Q-type channel with 24 polyglutamines (SCA624Q) exhibited normal gating properties whereas 40 expanded polyglutamines (SCA640Q) caused an hyperpolarizing shift in the voltage dependence of inactivation [57], suggesting an overall reduction of $\mathrm{Ca}^{2+}$ influx. On the contrary, another study revealed that showed the voltage dependence of inactivation of P/Q-type channels was negatively shifted in SCA624Q mice [58]. Recently, KI mice were generated by introducing hyperexpanded polyglutamines (SCA684Q) [59-62]. These mice develop progressive motor impairment in adult age. Extracellular recordings of cerebellar slices from SCA684Q mice revealed a decrease of Purkinje cell firing $(<100 \mathrm{~Hz})$ [63] accompanied by a reduction of the spike timing precision in spite of unchanged P/Q-type channel kinetics and current density, suggesting that expanded CAG repeat per se does not affect the intrinsic properties of the channels. In addition, surplus climbing fiber inputs on developing SCA684Q Purkinje cells were observed [63]. The aforementioned mouse models with intrinsic properties affected in $\mathrm{P} / \mathrm{Q}$-type channels, such as pore conduction, gating and inactivation kinetics, can provide further opportunities to understand how perturbations in $\mathrm{Ca}^{2+}$ signaling regulate neuronal excitation and its underlying relation with human SCAs.

\section{Mutations in the CACNA1G Gene}

SCA42 is a rare, autosomal dominant neurological disorder characterized by pure and slowly progressive cerebellar defects, including incoordination of gait, dysarthria, nystagmus, and saccadic eye movements (Table 1). Post-mortem histological examination revealed cerebellar atrophy in association with a prominent Purkinje cell loss [64]. A heterozygous single point mutation in the CACNA1G gene which causes an arginine-to-histidine ( .Arg1715His) change in the S4 voltage-sensing region of the T-type voltage-gated $\mathrm{Ca}^{2+}$ channel protein $\mathrm{Ca}(\mathrm{v}) 3.1$ has concurrently been associated to SCA42 in ten families [64-67]. T-type $\mathrm{Ca}^{2+}$ channels are widely expressed in the brain, including the thalamus, hippocampus, neocortex, and cerebellum [68]. In situ hybridization showed that $\mathrm{Ca}(\mathrm{v}) 3.1$ is the major isoform of T-type $\mathrm{Ca}^{2+}$ channels expressed in cerebellar motor circuit, including Purkinje cells, DCN and inferior olivary (IO) neurons, a result that is also supported by immunocytochemical localization [68-71]. The unique electrophysiological properties of T-type $\mathrm{Ca}^{2+}$ channels (especially the low voltage-activated $\mathrm{Ca}^{2+}$ current) are well suited to regulating neuronal excitability and oscillatory behavior near the resting membrane potential [72]. Specifically, T-type $\mathrm{Ca}^{2+}$ channels have a significant role in dendritic $\mathrm{Ca}^{2+}$ spikes and the resultant spontaneous bursts in Purkinje cells [73,74], whereas they mediate a rebound burst firing after hyperpolarization in DCN neurons [71] and underlie resonance and subthreshold membrane potential oscillations in IO neurons $[75,76]$. Recent findings on SCA42 using whole-exosome sequencing in HEK293T cells found that arginine-to-histidine change in CACNA1G gene was able to determine a positive shift of T-type $\mathrm{Ca}^{2+}$ channel voltage-dependence [65]. In order to elucidate whether this point mutation is implicated in the SCA42 phenotype, a new transgenic (Cacna1g-Arg1723His) mouse model, harboring the same mutation identified in the SCA42 families, has been generated [77]. Cacna1g-Arg1723His mice showed an adult-onset ataxic phenotype concomitant with cerebellar atrophy and Purkinje loss, as reported in human SCA42. Furthermore, Cacna1g-Arg1723His Purkinje cells displayed a change in the voltage-dependence of T-type $\mathrm{Ca}^{2+}$ channels which strongly impact on their excitability [77]. Interestingly, Hashiguchi's study also described that Arg1723His mutation altered the resonance properties of IO neurons, a result that has also been reported in $\mathrm{Ca}_{\mathrm{v}} 3.1 \mathrm{KO}$ mice [78,79]. Since $\mathrm{Ca}_{\mathrm{v}} 3.1 \mathrm{KO}$ mice are reported to have normal growth, normal brain weight and structure, and no significant defects in motor learning and motor coordination were observed $[80,81]$, the CACNA1G gene mutation most likely causes ataxic symptoms through a process different from a classic loss-of-function mechanism. 


\section{Mutations in the GRID2 Gene}

Recently, GRID2 point mutations with putative gain-of-function mechanisms were reported in several patients diagnosed with dominant inheritance of cerebellar ataxia [82]. They affect the same amino acid as that previously described by Phillips in Lurcher mouse model [83]. GRID2 gene encodes for the $\delta 2$ glutamate (GluD2) receptor, which is mostly expressed in Purkinje cells, where it is co-localized with AMPA receptors at the postsynaptic density (PSD) of parallel fiber synapses $[84,85]$. Although GluD2 receptors belong to the ionotropic glutamate receptor family [86], they are not gated by L-glutamate but selectively bind to D-serine and glycine [87]. GluD2 receptors are required for proper development and function of the cerebellum $[88,89]$. They play a crucial role in Purkinje cell synapse formation by interacting with presynaptic proteins $[87,90]$. Actually, several studies have demonstrated motor incoordination related to ataxia in GluD2 receptor KO mice. In addition, the number of contacts between parallel fiber and Purkinje cell is reduced while the innervation by climbing fibers into the distal part of the Purkinje cell dendritic tree is extended, thus invading the parallel fiber territory [89,91-93]. Furthermore, LTD impairment was observed at the parallel fiber-Purkinje cell synapse [89]. Homozygous Lurcher mice die at birth [94], whereas heterozygotes exhibit prominent ataxic gait and motor coordination deficit as a result of selective cell-autonomous apoptosis of Purkinje cells during the third postnatal week, when about $90 \%$ of the Purkinje cells have disappeared [95-97]. Lurcher Purkinje cells have a very high membrane conductance and a depolarized resting potential due to a large inward current resulting from continuous $\mathrm{Na}^{+}$and $\mathrm{Ca}^{2+}$ influx through constitutively open GluD2 receptors in the absence of ligand binding [6,97-99]. The mechanism by which continuous ion flow through mutated receptors is capable of inducing Purkinje cell death was proposed by [100] (Figure 1).

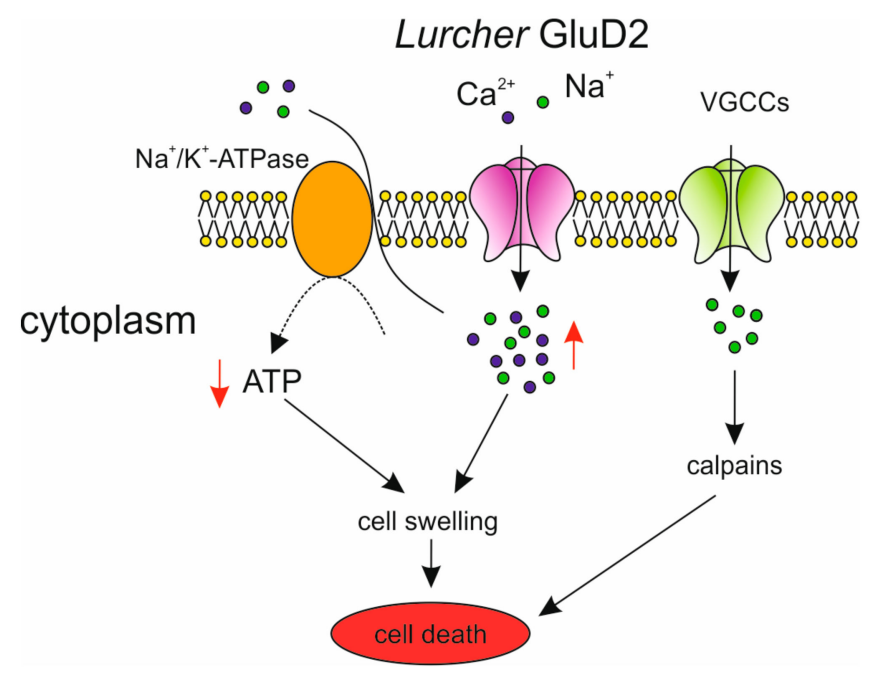

Figure 1. Lurcher $\delta 2$ glutamate (GluD2)-induced cell death. Lurcher GluD2 receptors show constitutive and continuous influx of $\mathrm{Na}^{+}$and $\mathrm{Ca}^{2+}$. Intracellular ATP levels are decreased probably by overactivation of the $\mathrm{Na}^{+} / \mathrm{K}^{+}$-ATPase. Compromised ionic homeostasis together with decreased ATP levels can lead to cell swelling and subsequent cell death. Secondary $\mathrm{Ca}^{2+}$ influx through voltage-gated $\mathrm{Ca}^{2+}$ channels (VGCCs) could activate a variety of $\mathrm{Ca}^{2+}$-dependent enzymes, such as calpains, and potentially contribute to Purkinje cell death through different pathways. Modified from [100].

In response to the constitutive ion influx through Lurcher GluD2 receptors, intracellular ATP levels decrease probably by overactivation of the $\mathrm{Na}^{+} / \mathrm{K}^{+}$-ATPase. Indeed, in Lurcher Purkinje cell dendrites, the mitochondrial oxidative respiration is increased in order to balance the energy demands of removing excess $\mathrm{Na}^{+}$and $\mathrm{Ca}^{2+}$ entering the cells in response to the constitutive GluD2 current [96]. Compromised ionic homeostasis together with decreased ATP levels can lead to cell swelling and subsequent cell death. Furthermore, $\mathrm{Ca}^{2+}$ influx through VGCCs could activate a variety of $\mathrm{Ca}^{2+}$-dependent enzymes, 
such as the cysteine protease calpain, and potentially contribute to Purkinje cell death through different pathways. Studies to assess the contribution of intracellular $\mathrm{Ca}^{2+}$ levels in triggering downstream pathways mediating Purkinje cell death in Lurcher mice will be directly relevant for our understanding the mechanisms of neurodegenerative diseases, such as SCAs. In conclusion, Lurcher mice will continue to be a valuable model for the development of disease-targeted therapeutic approaches.

\section{Mutations in the PRKCG Gene}

Spinocerebellar ataxia type 14 (SCA14; Table 1), characterized by slowly progressive cerebellar dysfunction, dysarthria and abnormal eye movements, is caused by almost 40 different mutations in PRKCG gene, encoding the protein kinase C gamma (PKC $\gamma$ ) $[19,101]$. PKC $\gamma$ is a member of the classical PKC subfamily which is activated by $\mathrm{Ca}^{2+}$ and the second messenger diacylglycerol (DAG), which is synthesized upon phosphatidylinositol 4,5-bisphosphate $\left(\mathrm{PIP}_{2}\right)$ hydrolysis by phospholipase $\mathrm{C}$ (PLC) [102]. Whereas an increase in intracellular $\mathrm{Ca}^{2+}$ concentration $\left(\left[\mathrm{Ca}^{2+}\right]_{\mathrm{i}}\right)$ is required to stimulate the cytosolic PKC $\gamma$ to translocate towards the plasma membrane, subsequent DAG binding is mandatory for enzyme activation. PKC $\gamma$ is expressed solely in the brain and spinal cord and its localization is restricted to neurons [103]. In the cerebellum, PKC $\gamma$ is most abundant in Purkinje cell soma and dendritic processes where it plays a role in normal development of the climbing fiber input from the inferior olive [104-107]. In both PKC $\gamma$ KO mice and mice expressing a transgenic PKC $\gamma$ inhibitor, multiple climbing fiber innervation of Purkinje cells persists into adulthood [106,108,109]. Nonetheless, the PKC $\gamma$ KO mice only show mild ataxia and no gross morphological abnormalities in Purkinje cells [106]. In contrast, cerebellar atrophy and loss of Purkinje cells were described at post-mortem in SCA14 patients $[110,111]$. These studies show the importance of PKC $\gamma$ activity in Purkinje cell development and neuronal connectivity and suggest the possibility that a gain of toxic function rather a loss of function of PKC $\gamma$ underlies the pathogenic mechanism of SCA14. A previous report showed that two SCA14 mutations led to increased PKC $\gamma$ intrinsic activity. The mutant kinase displays enhanced $\mathrm{Ca}^{2+}$-induced membrane translocation, which links Purkinje cell loss to a potential gain of PKC $\gamma$-mediated signal transduction [112]. More recently, Adachi and co-workers [113] have studied the PKC $\gamma$ activity in 20 spontaneous mutations found in PRKCG gene of SCA14 patients. Nineteen of the 20 mutations showed an increased PKC $\gamma$ activity although they were unable to bind DAG and their residency time within the plasma membrane was significantly shorter. As a consequence, the mutant PKC $\gamma$ could not phosphorylate and inhibit extracellular $\mathrm{Ca}^{2+}$ entry through Transient Receptor Potential Canonical 3 (TRPC3). Of note, TRPC3 provides a second messenger-operated $\mathrm{Ca}^{2+}$-entry pathway which is gated by DAG upon stimulation of metabotropic receptors [114]. As a consequence, $\left[\mathrm{Ca}^{2+}\right]_{i}$ is remarkably increased in the presence of mutant $\mathrm{PKC} \gamma$, thereby leading to aberrant intracellular signaling. These results indicate that an alteration in $\mathrm{Ca}^{2+}$ homeostasis and $\mathrm{Ca}^{2+}$-mediated signaling in Purkinje cells may be responsible for the neurodegeneration characteristic of SCA14. However, another report showed that SCA14 mutant PKC $\gamma$ activity is reduced in living cells causing an inefficient activation of downstream mitogen-activated protein kinase (MAPK) signaling. These events might therefore lead to reduced expression of target genes and affect neural development and survival $[115,116]$. To date, only two transgenic mouse models of SCA14 have been generated: PKC $\gamma$-H101Y and PKC $\gamma$-S361G mice, respectively $[117,118]$. Although the PKC $\gamma$-H101Y transgenic mouse express $\mathrm{H} 101 \mathrm{Y}$ mutation under a universal promoter, $\mathrm{PKC} \gamma-\mathrm{H} 101 \mathrm{Y}$ is peculiarly expressed in Purkinje cell soma and dendrites. The authors report an altered morphology and loss of Purkinje cells at the age of four weeks combined with an ataxic phenotype which is more severe than PKC $\gamma$ $\mathrm{KO}$ mice [117]. In the most recent transgenic mouse model of SCA14, by using the L7 promoter, the S361G mutation of the PKC $\gamma$ was specifically expressed in Purkinje cells [118]. Purkinje cells from PKC $\gamma$-S361G transgenic mice show severe inhibition of dendritic development which is identical to Purkinje cells treated with a PKC $\gamma$ agonist, motor deficits typical for cerebellar ataxias and Purkinje cell degeneration and loss in a localized area (lobule 7). These findings support the notion that the increased activity of PKC $\gamma$ results in the functional cerebellar deficit usually recognized in SCA14 
patients. Interestingly, point mutations inducing other forms of SCA often affect signaling proteins which are involved in the PKC $\gamma$ pathways, such as TRPC channels and inositol-1,4,5-trisphophoshate receptors $\left(\mathrm{IP}_{3} \mathrm{Rs}\right)$. Since $\mathrm{PKC} \gamma$ is likely to play a crucial role for proper Purkinje cell function, it might be an appealing drug target for the treatment of SCAs [118].

\section{Mutations in the TRPC 3 Gene}

The Moonwalker mouse ( $M k w)$ is a recently described model of dominantly inherited cerebellar ataxia that displays impaired motor and coordination control associated with a slow but progressive loss of Purkinje cells $[119,120]$. The phenotype is caused by a gain of function mutation (T365A) of the TRPC3 gene encoding for the $\mathrm{Ca}^{2+}$-permeable, non-selective cation channel TRPC3 (Transient Receptor Potential Canonical 3) [119-121]. TRPC3 mediates extracellular $\mathrm{Ca}^{2+}$ entry in response to

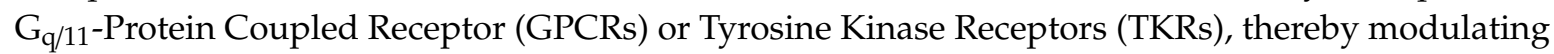
a host of several physiological functions, including synaptic transmission, arterial tone regulation and angiogenesis [122-127]. TRPC3 channels are abundantly expressed in the cerebellum, particularly in Purkinje cells and unipolar brush cells (UBCs), a small glutamatergic neurons mainly found in the granular layer of vestibulocerebellum $[119,128,129]$. During Purkinje cell postnatal development, TRPC3 channel expression is upregulated promoting a rapid dendritic growth and synapse formation [130]. Electrophysiological recordings from Trpc3 KO Purkinje cell have established that TRPC 3 channels mediate slow postsynaptic currents (sEPSCs) in response to stimulation of subtype I metabotropic glutamate receptors (mGluR1) $[123,129]$. When stimulated, mGluR1 activates PLC $\beta$ to hydrolize PIP 2 into $\mathrm{IP}_{3}$ and DAG [131]. As a consequence of $\mathrm{IP}_{3}$-induced endoplasmic reticulum (ER)- $\mathrm{Ca}^{2+}$ store depletion, the ER-Ca ${ }^{2+}$ sensor Stromal Interaction Molecule 1 (STIM1) translocates to peripheral ER cisternae, where it aggregates within sub-membranal clusters and gates Orai1 [132] and/or TRPC3 channels [133-136]. In addition to mediating sEPSCs (Hartmann et al., 2008), the functional coupling between mGluR1 and TRPC 3 channels was found to be critical for the induction of long-term depression (LTD) at the parallel fiber-Purkinje cell synapse [124,125]. Finally, a recent study has revealed that the difference in intrinsic firing activity of zebrin II-positive and zebrin II-negative Purkinje cells is generated by differential activity of TRPC 3 channels [137]. In the $M k w$ mutation, threonine 365 is converted into alanine in the highly conserved S4/S5 linker region of the TRPC3 protein leading to abnormal channel gating $[119,128]$. Accordingly, TRPC3 was activated following low mGluR1 stimulation in Mkw Purkinje cells (Becker et al., 2009). In addition, these cells are reduced in size and show a lower complexity of dendritic arborization which is characterized by few and short branches. Concurrent with dendritic abnormalities, a significant decrease in climbing fiber synapses along dendrites is observed $[119,120]$. UBCs are also severely reduced contributing to pronounced balance impairment of $M k w$ mice [128]. As $\mathrm{Ca}^{2+}$ signaling plays a fundamental role in regulating dendritogenesis and connectivity in the developing brain [138] and $M k w$ phenotype derives from a gain-of-function in the $\mathrm{Ca}^{2+}$-permeable TRPC3 channel, an abnormal $\mathrm{Ca}^{2+}$ influx during the critical period of development has been suggested to be the cause of limited dendritic arborization in Mkw Purkinje cells. Based upon the interaction between PKC $\gamma$ and TRPC3 described above, Becker and colleagues $[119,121,125]$ have proposed a model in which mGluR1-TRPC3-PKC $\gamma$ signaling at parallel fiber-Purkinje cell synapse is essential in controlling developmental and functional processes [129,130,139,140] (Figure 2). 


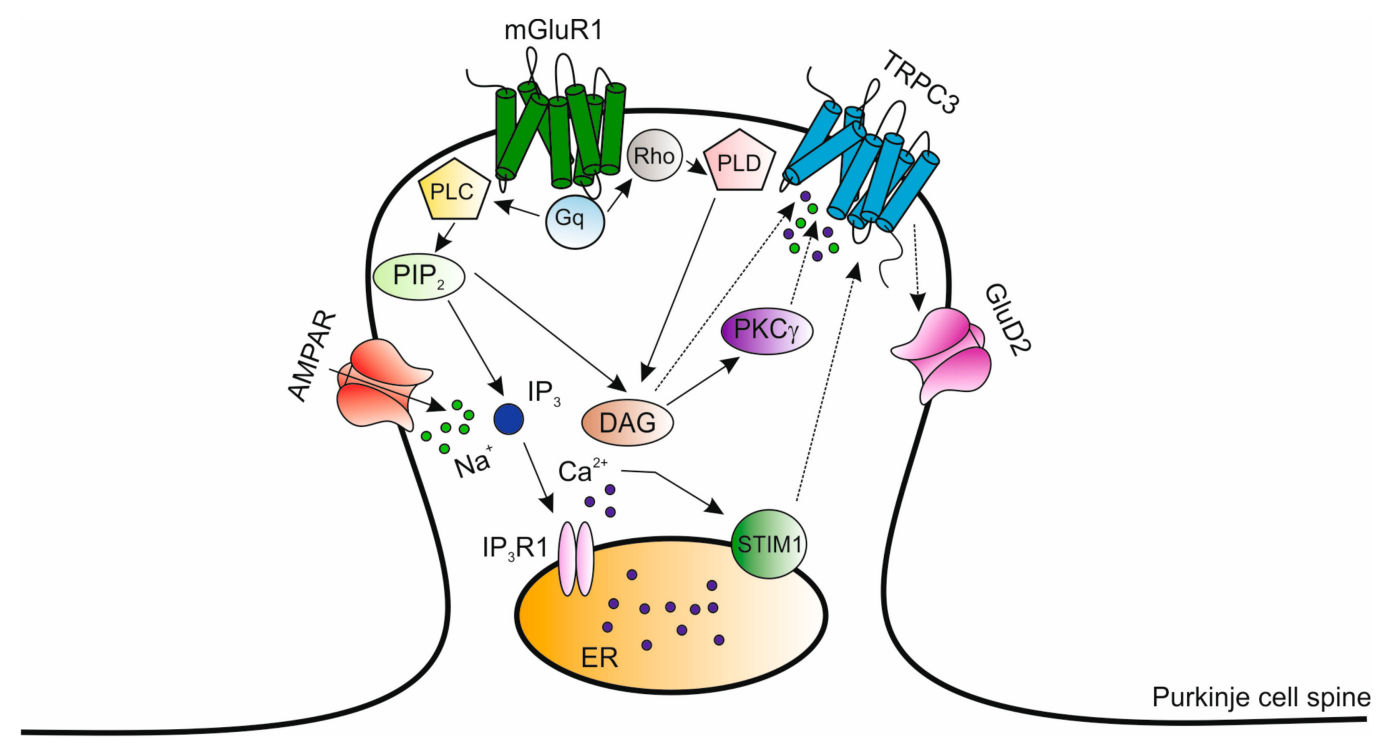

Figure 2. Subtype I metabotropic glutamate receptors-Transient Receptor Potential Canonical 3 (TRPC3)-PKC $\gamma$ (mGluR1-TRPC3-PKC $\gamma$ ) signaling at Purkinje cell synapse. TRPC3 channels and PKC $\gamma$ primarily respond to phospholipase C (PLC)-coupled receptors, such as mGluR1. TRPC3 channel activity is negatively regulated through phosphorylation by PKC $\gamma$. When stimulated, mGluR1 activates phospholipase C (PLC) which hydrolizes phosphatidylinositol 4,5-bisphosphate $\left(\mathrm{PIP}_{2}\right)$ into inositol 1,4,5-trisphosphate $\left(\mathrm{IP}_{3}\right)$ and diacylglycerol (DAG). Subsequently, the endoplasmic reticulum (ER)-Ca ${ }^{2+}$ store depletion by $\mathrm{IP}_{3}$ activates the ER $\mathrm{Ca}^{2+}$-sensor STIM1 which interacts with and activates TRPC3 channels. In addition, DAG has profound effects on the TRPC3 channels through PKC but it can also activate TRPC3 channels in a non-PKC-dependent manner. In turn, DAG formation is also promoted by mGluR1-dependent activation of phospholipase D (PLD) through the small GTP-binding protein Rho. In addition, mGluR1 activation triggers the opening of GluD2 receptors. Modified from [121].

TRPC3 channels are present in the same protein complex with mGluR1and both receptors localize to Purkinje cell soma and dendrites $[119,130,140]$. Moreover, TRPC3 channels and PKC $\gamma$ primarily respond to PLC-coupled receptors, such as mGluR1. Finally, TRPC3 channel activity has been shown to be negatively regulated through phosphorylation by PKC $\gamma$ at the distinct site of threonine 365, as also discussed above $[113,119,141,142]$. Thus, the absence of the PKC $\gamma$-mediated negative feedback on TRPC3 channels, which could occur upon mutations in the PRKCG gene, might determine a prolonged activation, resulting in sustained high levels of intracellular $\mathrm{Ca}^{2+}$ into Purkinje cells. Of note, besides modulating TRPC3 activity via PKC $\gamma$, DAG is also able to gate TRPC3 in a non-PKC-dependent manner [122]. Thus PKC is a powerful inhibitor of TRPC3 channels while DAG is a dual regulator [136]. In addition, TRPC3-mediated sEPSCs may be also induced following mGluR1-dependent activation of phospholipase D (PLD) through the small GTP-binding protein Rho [143]. In addition, recent studies have demonstrated that mGluR1 activation may be sustained by the physical association with the GluD2 receptors. GluD2 receptors share remarkable sequence homology with ionotropic glutamate receptors, although they neither bind to glutamate nor conduct ion currents [144]. A recent investigation demonstrated that mGluR1 may physically associate with GluD2, PKC $\gamma$, and TRPC3 in mouse cerebellar Purkinje neurons, thereby favoring the cell surface expression of the protein complex and boosting the efficacy of mGluR1-mediated synaptic transmission [145,146]. Perturbed TRPC3 signaling is likely to be a common pathological mechanisms in other genetic forms of cerebellar ataxia. Indeed, TRPC3 gene was recently identified as a central player in mouse models of SCA14 [113,129], SCA1 [147,148] and SCA2 [149] (see paragraphs above). SCA1 and SCA2 are caused by an abnormally expanded CAG-repeat sequence in the Ataxin-1 (ATXN1) and Ataxin-2 (ATXN2) genes, respectively. In transgenic mice expressing the human ATXN1 and ATXN2 genes with an expanded CAG tract under the Purkinje cell-specific Pcp2 promoter, TRPC3 gene was downregulated at an early stage in pathogenesis [148,149]. 
Intriguingly, the first functionally pathogenic variant in the human TRPC3 gene was identified in a patient with adult-onset cerebellar ataxia (SCA41; Table 1) [150,151]. Collectively, these findings point to a crucial role of TRPC3 signaling in hereditary forms of human cerebellar ataxia, making the TRPC3 gene a promising candidate for screening ataxic patients with unknown genetic etiology [152].

\section{Mutations in the Itpr1 Gene}

Inositol 1,4,5-trisphosphate receptors $\left(\mathrm{IP}_{3} \mathrm{Rs}\right)$ are intracellular $\mathrm{IP}_{3}$-gated channels that release $\mathrm{Ca}^{2+}$ from the endoplasmic reticulum (ER). $\mathrm{IP}_{3}$ is generated from $\mathrm{PIP}_{2}$ hydrolysis by PLC $\gamma$ and PLC $\beta$ in response to various extracellular stimuli acting on GPCRs and TKRs [153]. In mammals, including humans, the $\mathrm{IP}_{3} \mathrm{R}$ family consists of three isoforms (types 1-3) encoded by distinct genes (Itpr1, Itpr2, and Itpr3). Although human $\mathrm{IP}_{3} \mathrm{Rs}$ share around $70 \%$ sequence homology, they exhibit a different sensitivity to $\mathrm{IP}_{3}$ and tissue-/cell specific distribution [154-157]. $\mathrm{IP}_{3}$ receptor type $1\left(\mathrm{IP}_{3} \mathrm{R} 1\right)$ is primarily expressed in the cerebellum, especially in Purkinje cells, but it is also localized in other brain areas, including the cerebral cortex, basal ganglia, thalamus, and hippocampus [154,158-160]. Several reports suggest that abnormal $\mathrm{IP}_{3}$-mediated $\mathrm{Ca}^{2+}$ signaling is involved in the pathogenesis of spinocerebellar ataxia types 15/16 (SCA F; Table 1) and 29 (SCA29; Table 1), as well as other neurodegenerative disorders, such as Alzheimer's disease (AD) and Huntington's disease [161,162]. Van de Leemput and colleagues first described a heterozygous deletion of Itpr1 gene, encompassing exons 1-10, 1-40, and 1-44 in Australian and British families of patients for SCA15, which is characterized by the adult-onset of very slowly progressive gait and limb ataxia with episodic dystonic symptoms [163-167]. Soon after, a complete deletion of the gene was found in a Japanese patient with SCA15 [168]. A subsequent study reported only a heterozygous deletion limited to exons 1-48 of the Itpr 1 gene in a patient with SCA16 [169], indicating that haploinsufficiency of Itpr1 gene was the cause of both SCA15 and SCA16. Gardner proposed to designate SCA16 as a "vacant SCA"; however, the term SCA15/16 is still widely employed [170]. At least six different heterozygous point mutations have been identified in SCA29 which is distinguished by infantile-onset (congenital) motor development delay followed by non-progressive ataxia and mild cognitive impairment [171,172]. One of this mutation is located in the allosteric inhibitor of $\mathrm{IP}_{3} \mathrm{R} 1$, the carbonic anhydrase VIII-binding protein (Car8; [173]). There are two spontaneous mutant mice that naturally possess an Itprigene mutation, ITPR1 optopt $^{\text {of }}$ mice and ITPR $1^{\triangle 18 / \Delta 18}$ mice. Both the mouse models show a decrease in the normally high level of $\mathrm{IP}_{3} \mathrm{R} 1$ expression in the cerebellum $[164,174]$. Their phenotype start to show ataxic and convulsive phenotypes around 10 days after birth and die within 4 weeks $[164,175]$. In the regulatory domain of the Itpr1 gene, ITPR $1^{\text {optopt }}$ and ITPR $1^{\Delta 18 / \Delta 18}$ mice have a homologous in-frame deletion of exons $43 / 44$ and exon 36, respectively [164]. As a result of this deletion, several putative modulatory sites are removed $[154,175,176]$. Interestingly, the opt-IP ${ }_{3} \mathrm{R} 1$ seems to be more subject to proteolysis than the wild-type $\mathrm{IP}_{3} \mathrm{R} 1$ isoforms. Additionally, the single-channel conductance of the opt-IP $\mathrm{P}_{3} \mathrm{R} 1$ is reduced by $20 \%$ and sensitivity to potentiation by ATP is reduced 20-fold [177]. Surprisingly, Street and colleagues [175] reported that, despite markedly decreased $\mathrm{IP}_{3} \mathrm{R} 1$ protein level, repetitive mGluR stimulation elicited a supranormal $\mathrm{Ca}^{2+}$ release from ER in ITPR $1^{\text {opt } / \text { ppt }}$ Purkinje cells. These data suggest that the phenotype observed in ITPR $1^{\text {optopt }}$ mice may be caused by the physiological misregulation of a functional $\mathrm{IP}_{3} \mathrm{R} 1$. Currently, $\mathrm{Ca}^{2+}$ measurements and membrane electrophysiology would be necessary in order to ascertain whether ITPR $1^{\Delta 18 / \Delta 18}$ mice match the physiology of SCA15/16. Lastly, $\mathrm{IP}_{3} \mathrm{R} 1$ KO mice show a postnatal phenotype similar to those of ITPR1 $1^{\text {optopt }}$ and ITPR $1^{\Delta 18 / \Delta 18}$ mice $[178,179]$. Purkinje cells from $\mathrm{IP}_{3} \mathrm{R} 1 \mathrm{KO}$ mice exhibit abnormal dendritic arborization and enlarged parallel fiber terminals characterized by an accumulation of synaptic vesicles (Hisatsune et al., 2006). Hisatsune and colleagues suggested that BDNF production through $\mathrm{IP}_{3} \mathrm{R} 1$-mediated $\mathrm{Ca}^{2+}$ signaling in cerebellar granule cells intercellularly controls the dendritic outgrowth of Purkinje cells, resulting in altered parallel fiber-Purkinje cell synaptic efficacy. Indeed, electrophysiological experiments in $\mathrm{IP}_{3} \mathrm{R} 1 \mathrm{KO}$ mice demonstrated that long-term depression (LTD) at the parallel fiber-Purkinje cell synapse was impaired [180]. Furthermore, recordings in freely behaving conditional cerebellum/brainstem $\mathrm{IP}_{3} \mathrm{R} 1$ 
KO mice revealed distinct patterns of Purkinje cell firing linked to the dystonic symptoms which could be rescued by the deletion of Purkinje cells or by pharmacological inactivation of the inferior olive [181]. Taken together, the spectrum of ITPR1-associated phenotypes is intriguing. The heterozygous Itpr1gene deletions in late onset SCA15 suggest haploinsufficiency as a disease mechanism. Conversely, cases with a congenital or infantile onset of SCA29 appear to be caused exclusively by Itpr1 gene point mutation that alter the structure of $\mathrm{IP}_{3} \mathrm{R} 1$, presumably through a dominant negative effect [182].

\section{Mutations in the ATXN2/ATXN3 Genes}

SCA2 and SCA3 are two of the more prevalent polyQ diseases caused by CAG repeat expansion in the genes encoding ataxin-2 (Atxn2) and ataxin-3 (Atxn3) proteins which are widely expressed in neuronal tissue [183-189]. Typically, mutant proteins have an increased tendency to aggregate forming ubiquitinated microscopically visible intranuclear inclusions [189]. SCA2 is characterized by progressive cerebellar ataxia, dysarthria, and oculomotor deficits $[190,191]$ whereas SCA3, also known as Machado-Joseph disease (MJD), is a multi-systemic disorder affecting various different regions of the brain and spinal cord. Although the cerebellar cortex and olivary nuclei are relatively spared, high-resolution magnetic resonance imaging shows cerebellar atrophy. SCA3 is characterized by a broad spectrum of clinical signs involving cerebellar, pyramidal, extrapyramidal and spinal motor functions [192,193]. The role of $\mathrm{Ca}^{2+}$ signaling in the pathogenesis of SCA2 is supported by the genetic inverse correlation between CAG-repeat length in the CACNA1A gene and the age of disease onset [194] and further reinforced by finding that mutant Atxn2 has been shown to interact with the cytosolic $\mathrm{COOH}$-terminal of $\mathrm{IP}_{3} \mathrm{R} 1$ by increasing the sensitivity of the receptor to its ligand [20]. Transgenic animals expressing 58 glutamine repeats in the Atxn2 gene under the control of the L7 promoter (SCA2-58Q) exhibit Purkinje cell loss or marked changes in the Purkinje cell dendritic arborization, without nuclear localization or a detectable increase in ubiquitin-conjugated protein complexes [189]. These features are typical for SCA2 patient pathology. Moreover, specific behavioral assays quantified by rotarod and beam-walk analysis reveal age-dependent motor coordination deficits [20]. These reports are consistent with a gain-of-function or toxic gain-of-function of mutant Atxn2. In addition, mice deficient in Atxn2 do not show any evidence of ataxia or major morphological abnormalities in the cerebellar cortex [195]. This evidence further supports the notion that CAG repeat expansion in Atxn2 does not cause a loss of function nor does it have a dominant negative properties. Recent analyses of Purkinje cell pacemaking activity recorded from SCA2-58Q transgenic mice using extracellular single-unit in vivo recordings demonstrated an age-dependent bursting and irregular firing patterns [196,197]. Furthermore, $\mathrm{Ca}^{2+}$ imaging recordings showed a significant increase in $\mathrm{Ca}^{2+}$ release from $\mathrm{ER}$ via $\mathrm{IP}_{3} \mathrm{R} 1$ upon mGluR stimulation resulting in significantly more cell death [20]. Chronic suppression of $\mathrm{IP}_{3} \mathrm{R}$-mediated $\mathrm{Ca}^{2+}$ signaling by the over-expression of $\mathrm{IP}_{3}$ 5-phosphatase (5PP) using adeno-associated virus in aging SCA2-58Q transgenic mice has been shown to prevent Purkinje cell death, normalize their firing pattern, and attenuate motor coordination deficits [197]. The mechanism by which the $\mathrm{IP}_{3} \mathrm{R} 1$-mutant Atxn 2 interaction results in increased $\mathrm{IP}_{3} \mathrm{R} 1$ activity leading to deranged neuronal $\mathrm{Ca}^{2+}$ signaling was proposed by Kasumu and colleagues [22]. Aberrant $\mathrm{IP}_{3} \mathrm{R} 1$-dependent ER $\mathrm{Ca}^{2+}$ release results in the mitochondrial $\mathrm{Ca}^{2+}$ overload, release of cytochrome $\mathrm{C}$ and, consequently, induction of Purkinje cell death via dark cell degeneration (Figure 3), which represents a peculiar mode of excitotoxic cell death.

Interestingly, the positive modulation of small conductance $\mathrm{Ca}^{2+}$-gated $\mathrm{K}^{+}$channels type 2 (SK2), which are known to play an important role in the regulation of Purkinje cell spiking activity $[198,199]$, restores regular firing pattern of 58-Q Purkinje cells [200]. Furthermore, long-term feeding of aging SCA2-58Q transgenic mice with a novel selective positive modulator of SK2 channels (NS13001) improves motor performance [200]. This result identifies NS13001 as a potential therapeutic drug for treatment of SCA2. It is conventionally presumed that, except for Atxn2 which has an exclusively cytoplasmic localization in normal and SCA2 human brain [201], nuclear expression of CAG-expanded proteins is required for the pathogenesis of polyQ diseases [11,202,203]. Recently, genetic experiments, 
using transgenic mice expressing CAG-expanded Atxn3-79Q (SCA3-79Q), which display various symptoms of motor dysfunction, have confirmed the nuclear toxicity of mutant Atxn3 (Bichelmeier et al., 2007). In addition to forming toxic aggregates, single-channel recordings in reconstituted lipid bilayer membranes revealed that mutant $A t x n 3$ may increase $\mathrm{IP}_{3} \mathrm{R}$ activation by $\mathrm{IP}_{3}$, thus destabilizing neuronal $\mathrm{Ca}^{2+}$ signaling $[161,204]$. However, blocking the $\mathrm{Ca}^{2+}$-dependent proteiase, calpain, abrogated the formation of inclusions in cells expressing the mutant Atxn3 [205]. Moreover, in SCA3-79Q transgenic mice, pharmacological inhibition of $\mathrm{Ca}^{2+}$-induced $\mathrm{Ca}^{2+}$ release through ryanodine receptors (RyRs) was shown to counterbalance the increased activity of $\mathrm{IP}_{3} \mathrm{R} 1$, thereby resulting in an improvement of their performance in motor coordination assays [204]. These results strongly support the role of deranged $\mathrm{Ca}^{2+}$ signaling in the pathogenesis of SCA3. Finally, in SCA3-79Q transgenic mice, microarrays analysis and RT-PCR assays indicated downregulated expression of cerebellar genes involved in signal trasduction, neurotransmission or synaptic plasticity, including those encoding $\mathrm{IP}_{3} \mathrm{R} 1, \mathrm{PLC} \gamma$ and calcineurin [206]. Whole-cell patch-clamp recordings provided the evidence that mutant Atxn3-induced transcriptional repression impaired LTD induction at the parallel fiber-Purkinje cell synapse in SCA3-79Q mice [206]. These findings are at odds with the reported gain of function of $\mathrm{IP}_{3} \mathrm{R} 1$ following binding to the mutant Atxn3 [161,204]. These contradictory findings suggest that it could not be the reduced or increased activity of $\mathrm{IP}_{3} \mathrm{R} 1$ but rather the loss of a precise regulation of its activity that triggers the disease.

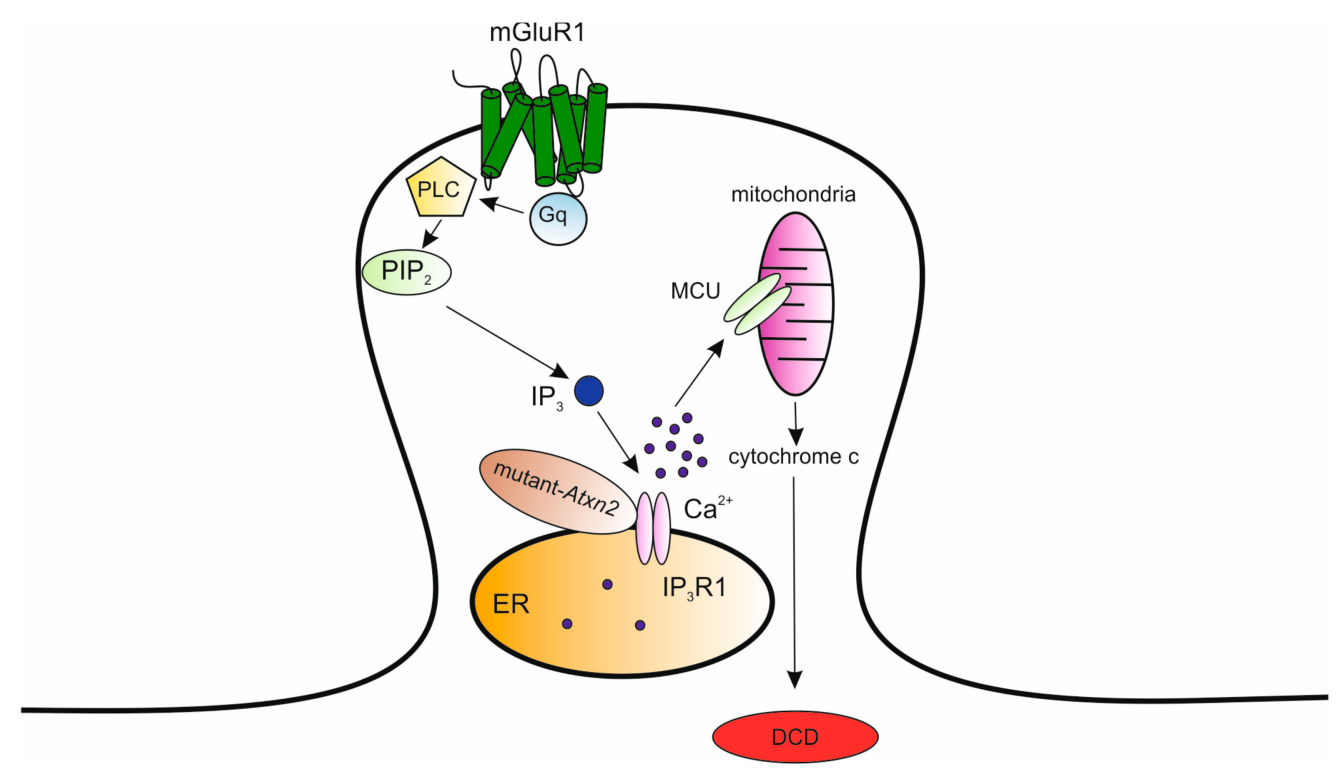

Figure 3. The $\mathrm{IP}_{3}$ receptor type $1\left(\mathrm{IP}_{3} \mathrm{R} 1\right)$-mutant $A t x n 2$ interaction-induced cell death. The $\mathrm{IP}_{3} \mathrm{R} 1-\mathrm{mutant}$ ataxin-2 (Atxn2) interaction results in increased $\mathrm{IP}_{3} \mathrm{R} 1$ activity. The abnormal $\mathrm{Ca}^{2+}$ signaling determines mitochondrial $\mathrm{Ca}^{2+}$ overload, release of cytochrome $\mathrm{C}$ and, consequently, induction of Purkinje cell death via dark cell degeneration (DCD). Modified from [22].

\section{Mutations in the ATXN1 Gene}

Expansion of CAG repeats within the ATXN1 gene encoded the cytosol/nuclear protein ataxin-1 (Atxn1) causes the adult-onset neurodegenerative disease SCA1 characterized by progressive ataxia, oculomotor deficits, pyramidal/extrapyramidal signs [207-211]. Atxn1 is widely expressed in the normal human brain and peripheral tissues. Immunohistochemical studies have revealed that Atxn1 is predominantly nuclear in neuronal cell types although Purkinje cells also present a minor cytoplasmic component [212]. The primary neurodegeneration in SCA1-affected individuals results in Purkinje cell loss and atrophy of specific brainstem neurons [208,213-216]. Moreover, nuclear inclusions consisting of the mutant Atxn1 have been described in neurons of SCA1 patients [217,218]. Interestingly, by using RNA in situ hybridization, high levels of Atxn1 expression in murine Purkinjie cells were detected 
during postnatal maturation when the growth of the dendritic tree is being completed and synaptic connections are being completed and becoming functional. This finding suggests that Atxn1 might play a role in Purkinje cell development and function [219,220]. Because the normal form of Atxn1 as well as Atxn1 with the expanded CAG repeat are transcribed and translated in the tissues of affected SCA1 patients, and the absence of Atxn1 in the mouse does not lead to any ataxic symptoms or major motor coordination abnormalities [221], the toxic-gain of function exerted by mutant Atxn1 has been suggested. In order to test this hypothesis, different SCA1 transgenic mice have been generated. The first transgenic mouse model of SCA1 employed the Purkinje cell-specific promoter L7 to precisely target the expression of the human ATXN1 gene [222]. Two lines were created with various repeat lengths; a control line with over-expression of the normal allele containing 30 CAG repeats (30Q), while the expansion construct contained 82 CAG repeats (82Q). ATXN1(30Q) mice exhibit a normal phenotype with no signs of neurological disorders. Conversely, ATXN1(82Q) mice reveal severe ataxia and progressive Purkinje cell loss [222-224]. ATXN1(82Q) Purkinje cells develop two pathological features described in cerebellar tissue from patients with SCA1: atrophic dendritic arborization and nuclear aggregates of mutant Atxn1 [224]. Using $\mathrm{Ca}^{2+}$-imaging and electrophysiological approaches in ATXN1(82Q) mice, a recent study reported a significant reduction in the responsiveness of Purkinje cells to climbing fiber activation at early-disease stage ( $\sim 6$ weeks) while parallel fiber-Purkinje cell transmission alteration occurred during SCA1 progression (28-40 weeks) [225]. Furthermore, immunofluorescent labeling of climbing fiber terminals revealed a reduction of climbing fiber synapses in the distal segment of the Purkinje cell dendritic tree resulting in incomplete innervation territory [225]. Finally, several specific genes involved in $\mathrm{Ca}^{2+}$ homeostasis have been shown to be sequentially downregulated in ATXN1(82Q) Purkinje cells, with $\mathrm{IP}_{3} \mathrm{R} 1$ and the Sarco-Endoplasmic Reticulum $\mathrm{Ca}^{2+}$-ATPase 2 (SERCA2) affected first, followed by TRPC 3 channels [148]. A similar downregulation has also been found in SCA1 human cerebellum. Moreover, changes in the dendritic expression of the $\mathrm{Ca}^{2+}$-binding proteins parvalbumin (PV) and calbindin D-28k (CaB) were observed [223,226]. Lastly, in order to assess the role of PV and $\mathrm{CaB}$ in the pathogenesis of SCA1, double mutant animals were generated by crossing $\mathrm{CaB} \mathrm{KO}$ with ATXN1(82Q) mice, leading to an increased disease phenotype [227]. Although indirectly, these findings strengthen the suggestion that the downregulation of proteins implicated in $\mathrm{Ca}^{2+}$ homeostasis and $\mathrm{Ca}^{2+}$ signaling in Purkinje cells can be an important component in the etiology of SCA1. Further understanding of $\mathrm{Ca}^{2+}$ signaling mechanisms could offer clues to the design of novel and effective therapeutic strategies for treatment of spinocerebellar ataxias.

\section{Mutations in the GMR1 Gene}

mGluR1, encoded by GRM1 gene, is one of the most abundant of its group of receptors in the mammalian central nervous system and is expressed at particularly high levels in Purkinje cells. Disease caused by mutations in GRM1 gene are extremely rare [228]. To date, the only GRM1 mutations identified have been found to cause an autosomal recessive spinocerebellar ataxia (SCAR13; [229]). Recently, Watson and colleagues reported heterozygous dominant mutations in GRM1 gene that are associated with distinct disease phenotypes: gain-of-function point mutations that lead to enhanced receptor activity causing an adult-onset cerebellar ataxia and a truncation mutation that result in a dominant-negative effect causing a juvenile-onset cerebellar ataxia characterized by cognitive impairment (SCA44; Table 1) [230]. mGluR1 loss of function has been revealed in some animal models of human cerebellar ataxia, such as SCA1 and SCA3 transgenic mice. In ATXN1(82Q) mice, it has been shown that the progressive loss of mGluR1 function is restored by the $\mathrm{GABA}_{\mathrm{B}}$ receptor agonist baclofen leading to rescue the motor coordination [223,231-233]. In SCA3 Purkinje cells, mGluR1 have been found to be mislocalized to non-synaptic site resulting in a disruption of mGluR1 signaling [234]. On other hand, mutations that causes a mGluR1 gain of function have been associated with SCA. For example, in SCA2-127Q transgenic mice, the significant increase in $\mathrm{Ca}^{2+}$ release from ER via $\mathrm{IP}_{3} \mathrm{R} 1$ caused by an amplification of mGluR1 signaling is prevented by buffering basal $\mathrm{Ca}^{2+}$ concentration at normal resting levels $[20,235,236]$. In conclusion, functional alteration of mGluR1 activity has been 
documented in different SCA mouse model, while, in human patients, several forms of cerebellar ataxia result from mutations in genes in this pathway, which suggests that disruption of mGluR1 signaling and downstream $\mathrm{Ca}^{2+}$ homeostasis form a common pathological mechanism underlying SCAs [21].

\section{Prospects for Therapeutic Development}

Currently, there is no preventive or curative treatment for SCAs, but over the last few years, several drugs and therapeutic strategies that potentially slow the disease progression are being tested. The therapeutic approaches can be divided into pharmacological and gene therapies that target the toxic downstream effect and stem cell replacement (neurotransplantation). Since disrupted Purkinje cell $\mathrm{Ca}^{2+}$ signaling has been identified as a common underlying mechanism in most of SCAs (Table 2), one pharmacological approach has been to propose that $\mathrm{Ca}^{2+}$ blockers and stabilizers have a potential utility for patients diagnosed with SCAs.

Table 2. Features of SCAs linked with abnormal $\mathrm{Ca}^{2+}$ signaling.

\begin{tabular}{|c|c|c|c|}
\hline SCA & Gene & Protein & Effect on $\mathrm{Ca}^{2+}$ Signaling \\
\hline SCA1 & ATXN1 & Ataxin-1 & Decrease \\
\hline SCA2 & ATXN2 & Ataxin-2 & Increase \\
\hline SCA3 & ATXN3 & Ataxin-3 & Increase \\
\hline SCA6 & CACNA1A & $\mathrm{Ca}^{2+}$ voltage-gated channel subunit $\alpha 1 \mathrm{~A}$ & Decrease \\
\hline SCA14 & PRKCG & PKC $\gamma$ & Increase/Decrease \\
\hline SCA15/16 & ITPR1 & $\mathrm{IP}_{3}$ receptor & Increase/Decrease \\
\hline SCA29 & ITPR1 & $\mathrm{IP}_{3}$ receptor & Decrease \\
\hline SCA41 & TRPC3 & TRPC3 channel & Increase \\
\hline SCA42 & CACNA1G & $\mathrm{Ca}^{2+}$ voltage-gated channel subunit $\alpha 1 \mathrm{G}$ & Decrease \\
\hline SCA44 & GMR1 & mGlu receptor 1 & Increase \\
\hline
\end{tabular}

Long-term feeding with intracellular dantrolene $\left(\mathrm{Ca}^{2+}\right.$ stabilizer) resulted in improved motor performance and decreased Purkinje cell loss in mouse models of SCA2 and SCA3 [20,204,237]. Similar effects were demonstrated for a novel Itpr1 inhibitor T-558 [238]. Another interesting pharmacological approach, with some preclinical success, has been the use of caffeine. In a mouse model of SCA3 administration of caffeine through the drinking water alleviated motor deficits [239]. Finally, the treatment with glutamate release inhibitor, riluzole, in a randomized placebo-controlled clinical trial in 40 SCA patients for 12 months (SCA1, 2, SCA6), improved ataxic symptoms [240]. Gene therapy has made great progress over the past decade, especially in the cases of the polyglutamine (polyQ)-repeat SCAs. Currently, the most encouraging and innovative are RNA-targeting therapies including RNA interference (RNAi) or antisense oligonucleotides (AONs), which have been validated in different mouse models [241]. RNAi is an evolutionarily process of post-transcriptional gene suppression initiated by double-stranded RNA sequences to reduce mRNA expression. RNAi can be induced by microRNAs (miRNA) or small hairpin RNA (shRNA). By causing a severe degradation of mRNA, miRNAs and shRNA are considered potent tools to achieve gene silencing. A recent study found that miRNA expression in the human cerebellum was downregulated in aging brain resulting in an increase of ATXN1 gene expression. Thus, the activation of miRNA in SCA1 brain could serve to reduce the cytotoxic effect of CAG expanded ATXN1 gene [242]. The potential use of shRNA as a therapeutic candidate in a mouse model of SCA1 was published in 2004 [243]. Intracerebellar stereotaxic injections of recombinant AAV expressing shRNA improved motor function, rescued cerebellar morphology and decreased Atxn1 inclusions in Purkinje cells. Finally, AONs are relatively short, single-stranded DNA/RNA sequences that can bind the target mRNA through Watson-Crick base pairing. This binding arrests translation and decreases synthesis of the encoded protein. SCA2 mice treated with intrathecal AONs injections displayed a reduced cerebellar ATXN2 expression associated with improvements in motor functions. Interestingly, Purkinje cell firing frequency returned to normal levels [244]. AONs have also been administered to SCA3 mice and were shown to sustain reduction 
of mutated Atxn3 and to rescue motor impairment. A correlation was also found with a recovery of defects in Purkinje cell firing frequency [245]. In recent years, stem cell-based clinical trials have taken the emerging field offering significant potential to deliver new treatments for SCAs. The first preclinical experiment into SCA1 mouse model has been published by Kaemmerer and Low (1999). They found that transplantation of embryonic cerebellar cells led to improvement in motor skills and enhancement in Purkinje cell survival [246]. Ten years later Chintawar and his colleagues [247] transplanted neural precursor cells derived from adult mice into SCA1 mouse cerebellum. These animals functioned better on behavioral tests and displayed more surviving Purkinje cells. Another study demonstrated that cerebellar neural stem cells transplanted into cerebellum of adult SCA3 mice alleviated motor impairments [248]. In SCA2 mouse model, the intravenous injection of human mesenchymal stem cells ameliorated the survival of Purkinje cells and motor performance and delayed the onset of disease [249]. Somatic cells that can be reprogrammed into iPSCs represent the last frontier within the stem cell-based therapy $[250,251]$. Currently, patient-derived SCA iPSCs are tested for drug screening and disease modelling [243,252,253]. First stem cell-based clinical trials in humans with cerebellar degeneration have already tested $[254,255]$. The findings support cerebellar transplantation as a promising therapy but intensive preclinical research is still necessary.

\section{Conclusions}

A wide variety of mutations causing ataxia reveals the central role of cerebellar Purkinje cells in the pathogenesis of motor dysfunctions in SCAs. Almost all ionic channels or receptors expressed by Purkinje cells involved in $\mathrm{Ca}^{2+}$ signaling or homeostasis, when mutated, cause ataxic symptoms but, currently, how their functions are altered in disease remain to be determined. Accumulating lines of evidence suggest that multiple cellular pathways are disrupted by majority of these mutated proteins in Purkinje cells [256], but the distinctive SCA pathogenesis does not begin until $\mathrm{Ca}^{2+}$ signaling pathways are deranged either as a result of an toxic increase or a suppression of compensatory mechanisms likely leading to the characteristic Purkinje cells loss, cerebellar atrophy, and ataxia. Additionally, alterations of any synaptic input to the Purkinje cells also cause ataxic symptoms. In the case of the parallel fiber synapse, the reduced number of contacts between parallel fiber and Purkinje cell, the extended innervation of the climbing fiber invading the parallel fiber territory and the LTD impairment are sufficient to cause motor symptoms related to ataxia, as in GluD2 mutant mice. In contrast, even a slight maturation disturbance of the climbing fiber-Purkinje cell synapse can cause acute motor deficits suggesting that the refinement of the CF projection causes more severe ataxia than the loss of cerebellar cortex output. Notably, extracellular $\mathrm{Ca}^{2+}$ influx through $\mathrm{Ca}(\mathrm{v}) 2.1$ is involved in development, functional differentiation and maturation of climbing fiber synapses. Studies on ataxic mutant mice have also resulted in the identification of other molecules involved in the phase of climbing fiber synapse elimination, such as PKC $\gamma$ and its downstream signal transduction pathway, as well as Atxn1. These mechanisms mentioned above could act independently or, more likely, interact and synergize with each other, triggering the accumulation of Purkinje cell damage that eventually leads to cerebellar dysfunction. This suggests that simultaneous targeting of several pathways might be therapeutically necessary to prevent neurodegeneration and preserve neuronal function [256].

Author Contributions: Writing-original draft preparation, F.P.; writing-review and editing, F.P. and F.M.; Funding acquisition, E.D. All authors have read and agreed to the published version of the manuscript.

Funding: This work has received funding from: the European Union's Horizon 2020 Framework Program for Research and Innovation under the Specific Grant Agreement No. 785907 (Human Brain Project SGA2) to E.D.; This research was funded by: Italian Ministry of Education, University and Research (MIUR): Dipartimenti di Eccellenza Program (2018-2022)—Dept. of Biology and Biotechnology "L. Spallanzani", University of Pavia to F.M.

Conflicts of Interest: The authors declare no conflict of interest. The funders had no role in the design of the design of the study; in the collection, analyses, or interpretation of data; in the writing of the manuscript, or in the decision to publish the results. 


\section{References}

1. D'Angelo, E.; Mazzarello, P.; Prestori, F.; Mapelli, J.; Solinas, S.; Lombardo, P.; Cesana, E.; Gandolfi, D.; Congi, L. The cerebellar network: From structure to function and dynamics. Brain Res. Rev. 2011, 66, 5-15. [CrossRef] [PubMed]

2. D'Angelo, E.; Mapelli, L.; Casellato, C.; Garrido, J.A.; Luque, N.; Monaco, J.; Prestori, F.; Pedrocchi, A.; Ros, E. Distributed Circuit Plasticity: New Clues for the Cerebellar Mechanisms of Learning. Cerebellum 2016, 15, 139-151. [CrossRef] [PubMed]

3. D'Angelo, E. The cerebellum gets social. Science 2019, 363, 229. [CrossRef] [PubMed]

4. Schmahmann, J.D.; Sherman, J.C. The cerebellar cognitive affective syndrome. Brain 1998, 121 Pt 4, 561-579. [CrossRef]

5. Strick, P.L.; Dum, R.P.; Fiez, J.A. Cerebellum and nonmotor function. Annu. Rev. Neurosci. 2009, 32, $413-434$. [CrossRef]

6. Cendelin, J. From mice to men: Lessons from mutant ataxic mice. Cerebellum Ataxias 2014, 1, 4. [CrossRef]

7. Manto, M.U. The wide spectrum of spinocerebellar ataxias (SCAs). Cerebellum 2005, 4, 2-6. [CrossRef]

8. Jayadev, S.; Bird, T.D. Hereditary ataxias: Overview. Genet. Med. 2013, 15, 673-683. [CrossRef]

9. Sullivan, R.; Yau, W.Y.; O'Connor, E.; Houlden, H. Spinocerebellar ataxia: An update. J. Neurol. 2019, 266, 533-544. [CrossRef]

10. Paulson, H.L. The spinocerebellar ataxias. J. Neuroophthalmol. 2009, 29, 227-237. [CrossRef]

11. Matilla-Duenas, A.; Sanchez, I.; Corral-Juan, M.; Davalos, A.; Alvarez, R.; Latorre, P. Cellular and molecular pathways triggering neurodegeneration in the spinocerebellar ataxias. Cerebellum 2010, 9, 148-166. [CrossRef] [PubMed]

12. Shimobayashi, E.; Kapfhammer, J.P. Calcium Signaling, PKC Gamma, IP3R1 and CAR8 Link Spinocerebellar Ataxias and Purkinje Cell Dendritic Development. Curr. Neuropharmacol. 2018, 16, 151-159. [CrossRef] [PubMed]

13. Underwood, B.R.; Rubinsztein, D.C. Spinocerebellar ataxias caused by polyglutamine expansions: A review of therapeutic strategies. Cerebellum 2008, 7, 215-221. [CrossRef] [PubMed]

14. Katsuno, M.; Banno, H.; Suzuki, K.; Takeuchi, Y.; Kawashima, M.; Tanaka, F.; Adachi, H.; Sobue, G. Molecular genetics and biomarkers of polyglutamine diseases. Curr. Mol. Med. 2008, 8, 221-234. [CrossRef] [PubMed]

15. Gupta, A.; Jankovic, J. Spinocerebellar ataxia 8: Variable phenotype and unique pathogenesis. Parkinsonism Relat. Disord. 2009, 15, 621-626. [CrossRef]

16. Ikeda, Y.; Daughters, R.S.; Ranum, L.P. Bidirectional expression of the SCA8 expansion mutation: One mutation, two genes. Cerebellum 2008, 7, 150-158. [CrossRef]

17. Klebe, S.; Durr, A.; Rentschler, A.; Hahn-Barma, V.; Abele, M.; Bouslam, N.; Schols, L.; Jedynak, P.; Forlani, S.; Denis, E.; et al. New mutations in protein kinase Cgamma associated with spinocerebellar ataxia type 14. Ann. Neurol. 2005, 58, 720-729. [CrossRef]

18. Ohata, T.; Yoshida, K.; Sakai, H.; Hamanoue, H.; Mizuguchi, T.; Shimizu, Y.; Okano, T.; Takada, F.; Ishikawa, K.; Mizusawa, H.; et al. A -16C > T substitution in the $5^{\prime}$ UTR of the puratrophin-1 gene is prevalent in autosomal dominant cerebellar ataxia in Nagano. J. Hum. Genet. 2006, 51, 461-466. [CrossRef]

19. Chen, D.H.; Raskind, W.H.; Bird, T.D. Spinocerebellar ataxia type 14. Handb. Clin. Neurol. 2012, 103, 555-559.

20. Liu, J.; Tang, T.S.; Tu, H.; Nelson, O.; Herndon, E.; Huynh, D.P.; Pulst, S.M.; Bezprozvanny, I. Deranged calcium signaling and neurodegeneration in spinocerebellar ataxia type 2. J. Neurosci. 2009, 29, 9148-9162. [CrossRef]

21. Schorge, S.; van de Leemput, J.; Singleton, A.; Houlden, H.; Hardy, J. Human ataxias: A genetic dissection of inositol triphosphate receptor (ITPR1)-dependent signaling. Trends Neurosci. 2010, 33, 211-219. [CrossRef] [PubMed]

22. Kasumu, A.; Bezprozvanny, I. Deranged calcium signaling in Purkinje cells and pathogenesis in spinocerebellar ataxia 2 (SCA2) and other ataxias. Cerebellum 2012, 11, 630-639. [CrossRef] [PubMed]

23. Grusser-Cornehls, U.; Baurle, J. Mutant mice as a model for cerebellar ataxia. Prog. Neurobiol. 2001, 63, 489-540. [CrossRef]

24. Shakkottai, V.G.; Chou, C.H.; Oddo, S.; Sailer, C.A.; Knaus, H.G.; Gutman, G.A.; Barish, M.E.; LaFerla, F.M.; Chandy, K.G. Enhanced neuronal excitability in the absence of neurodegeneration induces cerebellar ataxia. J. Clin. Investig. 2004, 113, 582-590. [CrossRef] 
25. Manto, M.; Marmolino, D. Animal models of human cerebellar ataxias: A cornerstone for the therapies of the twenty-first century. Cerebellum 2009, 8, 137-154. [CrossRef]

26. Ingram, M.A.; Orr, H.T.; Clark, H.B. Genetically engineered mouse models of the trinucleotide-repeat spinocerebellar ataxias. Brain Res. Bull. 2012, 88, 33-42. [CrossRef]

27. Ophoff, R.A.; Terwindt, G.M.; Vergouwe, M.N.; van Eijk, R.; Oefner, P.J.; Hoffman, S.M.; Lamerdin, J.E.; Mohrenweiser, H.W.; Bulman, D.E.; Ferrari, M.; et al. Familial hemiplegic migraine and episodic ataxia type-2 are caused by mutations in the $\mathrm{Ca}^{2+}$ channel gene CACNL1A4. Cell 1996, 87, 543-552. [CrossRef]

28. Zhuchenko, O.; Bailey, J.; Bonnen, P.; Ashizawa, T.; Stockton, D.W.; Amos, C.; Dobyns, W.B.; Subramony, S.H.; Zoghbi, H.Y.; Lee, C.C. Autosomal dominant cerebellar ataxia (SCA6) associated with small polyglutamine expansions in the alpha 1A-voltage-dependent calcium channel. Nat. Genet. 1997, 15, 62-69. [CrossRef]

29. Pietrobon, D. Biological science of headache channels. Handb. Clin. Neurol. 2010, 97, 73-83.

30. Tsien, R.W.; Tsien, R.Y. Calcium channels, stores, and oscillations. Annu. Rev. Cell Biol. 1990, 6, 715-760. [CrossRef]

31. Tsien, R.W.; Ellinor, P.T.; Horne, W.A. Molecular diversity of voltage-dependent $\mathrm{Ca}^{2+}$ channels. Trends Pharmacol. Sci. 1991, 12, 349-354. [CrossRef]

32. Llinas, R.R.; Sugimori, M.; Cherksey, B. Voltage-dependent calcium conductances in mammalian neurons. The P channel. Ann. N. Y. Acad. Sci. 1989, 560, 103-111. [CrossRef] [PubMed]

33. Usowicz, M.M.; Sugimori, M.; Cherksey, B.; Llinas, R. P-type calcium channels in the somata and dendrites of adult cerebellar Purkinje cells. Neuron 1992, 9, 1185-1199. [CrossRef]

34. Mintz, I.M.; Adams, M.E.; Bean, B.P. P-type calcium channels in rat central and peripheral neurons. Neuron 1992, 9, 85-95. [CrossRef]

35. Westenbroek, R.E.; Sakurai, T.; Elliott, E.M.; Hell, J.W.; Starr, T.V.; Snutch, T.P.; Catterall, W.A. Immunochemical identification and subcellular distribution of the alpha 1A subunits of brain calcium channels. J. Neurosci. 1995, 15, 6403-6418. [CrossRef] [PubMed]

36. Watanabe, S.; Takagi, H.; Miyasho, T.; Inoue, M.; Kirino, Y.; Kudo, Y.; Miyakawa, H. Differential roles of two types of voltage-gated $\mathrm{Ca}^{2+}$ channels in the dendrites of rat cerebellar Purkinje neurons. Brain Res. 1998, 791, 43-55. [CrossRef]

37. Miyazaki, T.; Hashimoto, K.; Shin, H.S.; Kano, M.; Watanabe, M. P/Q-Type Ca ${ }^{2+}$ Channel $\alpha 1 \mathrm{~A}$ Regulates Synaptic Competition on Developing Cerebellar Purkinje Cells. J. Neurosci. 2004, 24, 1734-1743. [CrossRef]

38. Noebels, J.L.; Sidman, R.L. Inherited epilepsy: Spike-wave and focal motor seizures in the mutant mouse tottering. Science 1979, 204, 1334-1336. [CrossRef]

39. Herrup, K.; Wilczynski, S.L. Cerebellar cell degeneration in the leaner mutant mouse. Neuroscience 1982, 7, 2185-2196. [CrossRef]

40. Campbell, D.B.; North, J.B.; Hess, E.J. Tottering mouse motor dysfunction is abolished on the Purkinje cell degeneration (pcd) mutant background. Exp. Neurol. 1999, 160, 268-278. [CrossRef]

41. Hoebeek, F.E.; Stahl, J.S.; van Alphen, A.M.; Schonewille, M.; Luo, C.; Rutteman, M.; van den Maagdenberg, A.M.; Molenaar, P.C.; Goossens, H.H.; Frens, M.A.; et al. Increased noise level of purkinje cell activities minimizes impact of their modulation during sensorimotor control. Neuron 2005, 45, 953-965. [CrossRef] [PubMed]

42. Stahl, J.S.; James, R.A.; Oommen, B.S.; Hoebeek, F.E.; De Zeeuw, C.I. Eye movements of the murine P/Q calcium channel mutant tottering, and the impact of aging. J. Neurophysiol. 2006, 95, 1588-1607. [CrossRef] [PubMed]

43. Wakamori, M.; Yamazaki, K.; Matsunodaira, H.; Teramoto, T.; Tanaka, I.; Niidome, T.; Sawada, K.; Nishizawa, Y.; Sekiguchi, N.; Mori, E.; et al. Single tottering mutations responsible for the neuropathic phenotype of the P-type calcium channel. J. Biol. Chem. 1998, 273, 34857-34867. [CrossRef] [PubMed]

44. Matsushita, K.; Wakamori, M.; Rhyu, I.J.; Arii, T.; Oda, S.; Mori, Y.; Imoto, K. Bidirectional alterations in cerebellar synaptic transmission of tottering and rolling $\mathrm{Ca}^{2+}$ channel mutant mice. J. Neurosci. 2002, 22, 4388-4398. [CrossRef]

45. Meier, H.; MacPike, A.D. Three syndromes produced by two mutant genes in the mouse. Clinical, pathological, and ultrastructural bases of tottering, leaner, and heterozygous mice. J. Hered. 1971, 62, 297-302. [CrossRef]

46. Isaacs, K.R.; Abbott, L.C. Cerebellar volume decreases in the tottering mouse are specific to the molecular layer. Brain Res. Bull. 1995, 36, 309-314. [CrossRef] 
47. Rhyu, I.J.; Abbott, L.C.; Walker, D.B.; Sotelo, C. An ultrastructural study of granule cell/Purkinje cell synapses in tottering ( $\operatorname{tg} / \operatorname{tg})$, leaner $(\operatorname{tg}(\operatorname{la}) / \operatorname{tg}(\mathrm{la}))$ and compound heterozygous tottering/leaner $(\operatorname{tg} / \operatorname{tg}(\operatorname{la}))$ mice. Neuroscience 1999, 90, 717-728. [CrossRef]

48. Oda, S. The observation of rolling mouse Nagoya (rol), a new neurological mutant, and its maintenance (author's transl). Jikken Dobutsu 1973, 22, 281-288.

49. Plomp, J.J.; van den Maagdenberg, A.M.; Kaja, S. The ataxic Cacna1a-mutant mouse rolling nagoya: An overview of neuromorphological and electrophysiological findings. Cerebellum 2009, 8, 222-230. [CrossRef]

50. Heckroth, J.A.; Abbott, L.C. Purkinje cell loss from alternating sagittal zones in the cerebellum of leaner mutant mice. Brain Res. 1994, 658, 93-104. [CrossRef]

51. Fukumoto, N.; Kitamura, N.; Niimi, K.; Takahashi, E.; Itakura, C.; Shibuya, I. $\mathrm{Ca}^{2+}$ channel currents in dorsal root ganglion neurons of $\mathrm{P} / \mathrm{Q}-$ type voltage-gated $\mathrm{Ca}^{2+}$ channel mutant mouse, rolling mouse Nagoya. Neurosci. Res. 2012, 73, 199-206. [CrossRef] [PubMed]

52. Mori, Y.; Wakamori, M.; Oda, S.; Fletcher, C.F.; Sekiguchi, N.; Mori, E.; Copeland, N.G.; Jenkins, N.A.; Matsushita, K.; Matsuyama, Z.; et al. Reduced voltage sensitivity of activation of P/Q-type Ca ${ }^{2+}$ channels is associated with the ataxic mouse mutation rolling Nagoya (tg(rol)). J. Neurosci. 2000, 20, 5654-5662. [CrossRef] [PubMed]

53. Tokuda, S.; Kuramoto, T.; Tanaka, K.; Kaneko, S.; Takeuchi, I.K.; Sasa, M.; Serikawa, T. The ataxic groggy rat has a missense mutation in the $\mathrm{P} / \mathrm{Q}$-type voltage-gated $\mathrm{Ca}^{2+}$ channel alpha1A subunit gene and exhibits absence seizures. Brain Res. 2007, 1133, 168-177. [CrossRef] [PubMed]

54. Xie, G.; Clapcote, S.J.; Nieman, B.J.; Tallerico, T.; Huang, Y.; Vukobradovic, I.; Cordes, S.P.; Osborne, L.R.; Rossant, J.; Sled, J.G.; et al. Forward genetic screen of mouse reveals dominant missense mutation in the P/Q-type voltage-dependent calcium channel, CACNA1A. Genes Brain Behav. 2007, 6, 717-727. [CrossRef]

55. Kojic, M.; Gaik, M.; Kiska, B.; Salerno-Kochan, A.; Hunt, S.; Tedoldi, A.; Mureev, S.; Jones, A.; Whittle, B.; Genovesi, L.A.; et al. Elongator mutation in mice induces neurodegeneration and ataxia-like behavior. Nat. Commun. 2018, 9, 3195. [CrossRef]

56. Miki, T.; Zwingman, T.A.; Wakamori, M.; Lutz, C.M.; Cook, S.A.; Hosford, D.A.; Herrup, K.; Fletcher, C.F.; Mori, Y.; Frankel, W.N.; et al. Two novel alleles of tottering with distinct $\mathrm{Ca}(\mathrm{v}) 2.1$ calcium channel neuropathologies. Neuroscience 2008, 155, 31-44. [CrossRef]

57. Matsuyama, Z.; Wakamori, M.; Mori, Y.; Kawakami, H.; Nakamura, S.; Imoto, K. Direct alteration of the $\mathrm{P} / \mathrm{Q}$-type $\mathrm{Ca}^{2+}$ channel property by polyglutamine expansion in spinocerebellar ataxia 6. J. Neurosci. 1999, 19, Rc14. [CrossRef]

58. Toru, S.; Murakoshi, T.; Ishikawa, K.; Saegusa, H.; Fujigasaki, H.; Uchihara, T.; Nagayama, S.; Osanai, M.; Mizusawa, H.; Tanabe, T. Spinocerebellar ataxia type 6 mutation alters P-type calcium channel function. J. Biol. Chem. 2000, 275, 10893-10898. [CrossRef]

59. Saegusa, H.; Wakamori, M.; Matsuda, Y.; Wang, J.; Mori, Y.; Zong, S.; Tanabe, T. Properties of human Cav2.1 channel with a spinocerebellar ataxia type 6 mutation expressed in Purkinje cells. Mol. Cell. Neurosci. 2007, 34, 261-270. [CrossRef]

60. Watase, K.; Barrett, C.F.; Miyazaki, T.; Ishiguro, T.; Ishikawa, K.; Hu, Y.; Unno, T.; Sun, Y.; Kasai, S.; Watanabe, M.; et al. Spinocerebellar ataxia type 6 knockin mice develop a progressive neuronal dysfunction with age-dependent accumulation of mutant CaV2.1 channels. Proc. Natl. Acad. Sci. USA 2008, 105, 11987-11992. [CrossRef]

61. Watase, K. Spinocerebellar ataxia type 6: Lessons from faithfull knck-in mouse models. Neurol. Clin. Neurosci. 2015, 3, 14-17. [CrossRef]

62. Jayabal, S.; Ljungberg, L.; Erwes, T.; Cormier, A.; Quilez, S.; El Jaouhari, S.; Watt, A.J. Rapid Onset of Motor Deficits in a Mouse Model of Spinocerebellar Ataxia Type 6 Precedes Late Cerebellar Degeneration1,2,3. eNeuro 2015, 2. [CrossRef] [PubMed]

63. Jayabal, S.; Ljungberg, L.; Watt, A.J. Transient cerebellar alterations during development prior to obvious motor phenotype in a mouse model of spinocerebellar ataxia type 6. J. Physiol. 2017, 595, 949-966. [CrossRef] [PubMed]

64. Coutelier, M.; Blesneac, I.; Monteil, A.; Monin, M.L.; Ando, K.; Mundwiller, E.; Brusco, A.; Le Ber, I.; Anheim, M.; Castrioto, A.; et al. A Recurrent Mutation in CACNA1G Alters Cav3.1 T-Type Calcium-Channel Conduction and Causes Autosomal-Dominant Cerebellar Ataxia. Am. J. Hum. Genet. 2015, 97, 726-737. [CrossRef] 
65. Morino, H.; Matsuda, Y.; Muguruma, K.; Miyamoto, R.; Ohsawa, R.; Ohtake, T.; Otobe, R.; Watanabe, M.; Maruyama, H.; Hashimoto, K.; et al. A mutation in the low voltage-gated calcium channel CACNA1G alters the physiological properties of the channel, causing spinocerebellar ataxia. Mol. Brain 2015, 8, 89. [CrossRef]

66. Kimura, M.; Yabe, I.; Hama, Y.; Eguchi, K.; Ura, S.; Tsuzaka, K.; Tsuji, S.; Sasaki, H. SCA42 mutation analysis in a case series of Japanese patients with spinocerebellar ataxia. J. Hum. Genet. 2017, 62, 857-859. [CrossRef]

67. Ngo, K.; Aker, M.; Petty, L.E.; Chen, J.; Cavalcanti, F.; Nelson, A.B.; Hassin-Baer, S.; Geschwind, M.D.; Perlman, S.; Italiano, D.; et al. Expanding the global prevalence of spinocerebellar ataxia type 42. Neurol. Genet. 2018, 4, e232. [CrossRef]

68. Talley, E.M.; Cribbs, L.L.; Lee, J.H.; Daud, A.; Perez-Reyes, E.; Bayliss, D.A. Differential distribution of three members of a gene family encoding low voltage-activated (T-type) calcium channels. J. Neurosci. 1999, 19, 1895-1911. [CrossRef]

69. Yunker, A.M. Modulation and pharmacology of low voltage-activated ("T-Type") calcium channels. J. Bioenerg. Biomembr. 2003, 35, 577-598. [CrossRef]

70. Craig, P.J.; Beattie, R.E.; Folly, E.A.; Banerjee, M.D.; Reeves, M.B.; Priestley, J.V.; Carney, S.L.; Sher, E.; Perez-Reyes, E.; Volsen, S.G. Distribution of the voltage-dependent calcium channel alpha1G subunit mRNA and protein throughout the mature rat brain. Eur. J. Neurosci. 1999, 11, 2949-2964. [CrossRef]

71. Molineux, M.L.; McRory, J.E.; McKay, B.E.; Hamid, J.; Mehaffey, W.H.; Rehak, R.; Snutch, T.P.; Zamponi, G.W.; Turner, R.W. Specific T-type calcium channel isoforms are associated with distinct burst phenotypes in deep cerebellar nuclear neurons. Proc. Natl. Acad. Sci. USA 2006, 103, 5555-5560. [CrossRef] [PubMed]

72. Weiss, N.; Zamponi, G.W. T-type calcium channels: From molecule to therapeutic opportunities. Int. J. Biochem. Cell. Biol. 2019, 108, 34-39. [CrossRef] [PubMed]

73. Swensen, A.M.; Bean, B.P. Ionic Mechanisms of Burst Firing in Dissociated Purkinje Neurons. J. Neurosci. 2003, 23, 9650-9663. [CrossRef] [PubMed]

74. Womack, M.D.; Khodakhah, K. Dendritic control of spontaneous bursting in cerebellar Purkinje cells. J. Neurosci. 2004, 24, 3511-3521. [CrossRef]

75. Hildebrand, M.E.; Isope, P.; Miyazaki, T.; Nakaya, T.; Garcia, E.; Feltz, A.; Schneider, T.; Hescheler, J.; Kano, M.; Sakimura, K.; et al. Functional coupling between mGluR1 and Cav3.1 T-type calcium channels contributes to parallel fiber-induced fast calcium signaling within Purkinje cell dendritic spines. J. Neurosci. 2009, 29, 9668-9682. [CrossRef]

76. Ly, R.; Bouvier, G.; Schonewille, M.; Arabo, A.; Rondi-Reig, L.; Lena, C.; Casado, M.; De Zeeuw, C.I.; Feltz, A. T-type channel blockade impairs long-term potentiation at the parallel fiber-Purkinje cell synapse and cerebellar learning. Proc. Natl. Acad. Sci. USA 2013, 110, 20302-20307. [CrossRef]

77. Hashiguchi, S.; Doi, H.; Kunii, M.; Nakamura, Y.; Shimuta, M.; Suzuki, E.; Koyano, S.; Okubo, M.; Kishida, H.; Shiina, M.; et al. Ataxic phenotype with altered CaV3.1 channel property in a mouse model for spinocerebellar ataxia 42. Neurobiol. Dis. 2019, 130, 104516. [CrossRef]

78. Matsumoto-Makidono, Y.; Nakayama, H.; Yamasaki, M.; Miyazaki, T.; Kobayashi, K.; Watanabe, M.; Kano, M.; Sakimura, K.; Hashimoto, K. Ionic Basis for Membrane Potential Resonance in Neurons of the Inferior Olive. Cell Rep. 2016, 16, 994-1004. [CrossRef]

79. Choi, S.; Yu, E.; Kim, D.; Urbano, F.J.; Makarenko, V.; Shin, H.S.; Llinas, R.R. Subthreshold membrane potential oscillations in inferior olive neurons are dynamically regulated by P/Q- and T-type calcium channels: A study in mutant mice. J. Physiol. 2010, 588 Pt 16, 3031-3043. [CrossRef]

80. Kim, D.; Song, I.; Keum, S.; Lee, T.; Jeong, M.J.; Kim, S.S.; McEnery, M.W.; Shin, H.S. Lack of the burst firing of thalamocortical relay neurons and resistance to absence seizures in mice lacking alpha(1G) T-type $\mathrm{Ca}(2+)$ channels. Neuron 2001, 31, 35-45. [CrossRef]

81. Park, Y.G.; Park, H.Y.; Lee, C.J.; Choi, S.; Jo, S.; Choi, H.; Kim, Y.H.; Shin, H.S.; Llinas, R.R.; Kim, D. Ca(V)3.1 is a tremor rhythm pacemaker in the inferior olive. Proc. Natl. Acad. Sci. USA 2010, 107, 10731-10736. [CrossRef] [PubMed]

82. Coutelier, M.; Burglen, L.; Mundwiller, E.; Abada-Bendib, M.; Rodriguez, D.; Chantot-Bastaraud, S.; Rougeot, C.; Cournelle, M.A.; Milh, M.; Toutain, A.; et al. GRID2 mutations span from congenital to mild adult-onset cerebellar ataxia. Neurology 2015, 84, 1751-1759. [CrossRef] [PubMed]

83. Phillips, R. "Lurcher", a new gene in linkage group XI of the house mouse. J. Genet. 1960, 57, 35-42. [CrossRef] 
84. Takayama, C.; Nakagawa, S.; Watanabe, M.; Mishina, M.; Inoue, Y. Developmental changes in expression and distribution of the glutamate receptor channel delta 2 subunit according to the Purkinje cell maturation. Dev. Brain Res. 1996, 92, 147-155. [CrossRef]

85. Landsend, A.S.; Amiry-Moghaddam, M.; Matsubara, A.; Bergersen, L.; Usami, S.; Wenthold, R.J.; Ottersen, O.P. Differential localization of delta glutamate receptors in the rat cerebellum: Coexpression with AMPA receptors in parallel fiber-spine synapses and absence from climbing fiber-spine synapses. J. Neurosci. 1997, 17, 834-842. [CrossRef]

86. Yamazaki, M.; Mori, H.; Araki, K.; Mori, K.J.; Mishina, M. Cloning, expression and modulation of a mouse NMDA receptor subunit. FEBS Lett. 1992, 300, 39-45. [CrossRef]

87. Hirai, H.; Miyazaki, T.; Kakegawa, W.; Matsuda, S.; Mishina, M.; Watanabe, M.; Yuzaki, M. Rescue of abnormal phenotypes of the delta2 glutamate receptor-null mice by mutant delta2 transgenes. EMBO Rep. 2005, 6, 90-95. [CrossRef]

88. Kakegawa, W.; Miyazaki, T.; Kohda, K.; Matsuda, K.; Emi, K.; Motohashi, J.; Watanabe, M.; Yuzaki, M. The N-terminal domain of GluD2 (GluRdelta2) recruits presynaptic terminals and regulates synaptogenesis in the cerebellum in vivo. J. Neurosci. 2009, 29, 5738-5748. [CrossRef]

89. Kashiwabuchi, N.; Ikeda, K.; Araki, K.; Hirano, T.; Shibuki, K.; Takayama, C.; Inoue, Y.; Kutsuwada, T.; Yagi, T.; Kang, Y.; et al. Impairment of motor coordination, Purkinje cell synapse formation, and cerebellar long-term depression in GluR delta 2 mutant mice. Cell 1995, 81, 245-252. [CrossRef]

90. Uemura, T.; Mishina, M. The amino-terminal domain of glutamate receptor delta2 triggers presynaptic differentiation. Biochem. Biophys. Res. Commun. 2008, 377, 1315-1319. [CrossRef]

91. Kurihara, H.; Hashimoto, K.; Kano, M.; Takayama, C.; Sakimura, K.; Mishina, M.; Inoue, Y.; Watanabe, M. Impaired parallel fiber $\rightarrow$ Purkinje cell synapse stabilization during cerebellar development of mutant mice lacking the glutamate receptor delta2 subunit. J. Neurosci. 1997, 17, 9613-9623. [CrossRef] [PubMed]

92. Ichikawa, R.; Miyazaki, T.; Kano, M.; Hashikawa, T.; Tatsumi, H.; Sakimura, K.; Mishina, M.; Inoue, Y.; Watanabe, M. Distal extension of climbing fiber territory and multiple innervation caused by aberrant wiring to adjacent spiny branchlets in cerebellar Purkinje cells lacking glutamate receptor delta 2. J. Neurosci. 2002, 22, 8487-8503. [CrossRef] [PubMed]

93. Miyoshi, Y.; Yoshioka, Y.; Suzuki, K.; Miyazaki, T.; Koura, M.; Saigoh, K.; Kajimura, N.; Monobe, Y.; Kusunoki, S.; Matsuda, J.; et al. A new mouse allele of glutamate receptor delta 2 with cerebellar atrophy and progressive ataxia. PLoS ONE 2014, 9, e107867. [CrossRef] [PubMed]

94. Cheng, S.S.; Heintz, N. Massive loss of mid- and hindbrain neurons during embryonic development of homozygous lurcher mice. J. Neurosci. 1997, 17, 2400-2407. [CrossRef] [PubMed]

95. Lalonde, R.; Botez, M.I.; Joyal, C.C.; Caumartin, M. Motor abnormalities in lurcher mutant mice. Physiol. Behav. 1992, 51, 523-525. [CrossRef]

96. Vogel, M.W.; Caston, J.; Yuzaki, M.; Mariani, J. The Lurcher mouse: Fresh insights from an old mutant. Brain Res. 2007, 1140, 4-18. [CrossRef]

97. Zuo, J.; De Jager, P.L.; Takahashi, K.A.; Jiang, W.; Linden, D.J.; Heintz, N. Neurodegeneration in Lurcher mice caused by mutation in delta2 glutamate receptor gene. Nature 1997, 388, 769-773. [CrossRef]

98. Wollmuth, L.P.; Kuner, T.; Jatzke, C.; Seeburg, P.H.; Heintz, N.; Zuo, J. The Lurcher mutation identifies delta 2 as an AMPA/kainate receptor-like channel that is potentiated by $\mathrm{Ca}(2+)$. J. Neurosci. 2000, 20, 5973-5980. [CrossRef]

99. Nishiyama, J.; Matsuda, K.; Kakegawa, W.; Yamada, N.; Motohashi, J.; Mizushima, N.; Yuzaki, M. Reevaluation of neurodegeneration in lurcher mice: Constitutive ion fluxes cause cell death with, not by, autophagy. J. Neurosci. 2010, 30, 2177-2187. [CrossRef]

100. Nishiyama, J.; Yuzaki, M. Excitotoxicity and autophagy: Lurcher may not be a model of "autophagic cell death". Autophagy 2010, 6, 568-570. [CrossRef]

101. Chen, D.H.; Brkanac, Z.; Verlinde, C.L.; Tan, X.J.; Bylenok, L.; Nochlin, D.; Matsushita, M.; Lipe, H.; Wolff, J.; Fernandez, M.; et al. Missense mutations in the regulatory domain of PKC gamma: A new mechanism for dominant nonepisodic cerebellar ataxia. Am. J. Hum. Genet. 2003, 72, 839-849. [CrossRef] [PubMed]

102. Guerra, G.; Lucariello, A.; Perna, A.; Botta, L.; De Luca, A.; Moccia, F. The Role of Endothelial Ca(2+) Signaling in Neurovascular Coupling: A View from the Lumen. Int. J. Mol. Sci. 2018, 19, 938. [CrossRef] [PubMed] 
103. Saito, N.; Shirai, Y. Protein kinase C gamma (PKC gamma): Function of neuron specific isotype. J. Biochem. 2002, 132, 683-687. [CrossRef] [PubMed]

104. Hirai, H. Protein Kinase C in the Cerebellum: Its Significance and Remaining Conundrums. Cerebellum 2018, 17, 23-27. [CrossRef]

105. Moriya, M.; Tanaka, S. Prominent expression of protein kinase C (gamma) mRNA in the dendrite-rich neuropil of mice cerebellum at the critical period for synaptogenesis. Neuroreport 1994, 5, 929-932. [CrossRef]

106. Kano, M.; Hashimoto, K.; Chen, C.; Abeliovich, A.; Aiba, A.; Kurihara, H.; Watanabe, M.; Inoue, Y.; Tonegawa, S. Impaired synapse elimination during cerebellar development in PKC gamma mutant mice. Cell 1995, 83, 1223-1231. [CrossRef]

107. Barmack, N.H.; Qian, Z.; Yoshimura, J. Regional and cellular distribution of protein kinase C in rat cerebellar Purkinje cells. J. Comp. Neurol. 2000, 427, 235-254. [CrossRef]

108. Chen, C.; Kano, M.; Abeliovich, A.; Chen, L.; Bao, S.; Kim, J.J.; Hashimoto, K.; Thompson, R.F.; Tonegawa, S. Impaired motor coordination correlates with persistent multiple climbing fiber innervation in PKC gamma mutant mice. Cell 1995, 83, 1233-1242. [CrossRef]

109. De Zeeuw, C.I.; Simpson, J.I.; Hoogenraad, C.C.; Galjart, N.; Koekkoek, S.K.; Ruigrok, T.J. Microcircuitry and function of the inferior olive. Trends Neurosci. 1998, 21, 391-400. [CrossRef]

110. Van de Warrenburg, B.P.; Verbeek, D.S.; Piersma, S.J.; Hennekam, F.A.; Pearson, P.L.; Knoers, N.V.; Kremer, H.P.; Sinke, R.J. Identification of a novel SCA14 mutation in a Dutch autosomal dominant cerebellar ataxia family. Neurology 2003, 61, 1760-1765. [CrossRef]

111. Brkanac, Z.; Bylenok, L.; Fernandez, M.; Matsushita, M.; Lipe, H.; Wolff, J.; Nochlin, D.; Raskind, W.H.; Bird, T.D. A new dominant spinocerebellar ataxia linked to chromosome 19q13.4-qter. Arch. Neurol. 2002, 59, 1291-1295. [CrossRef] [PubMed]

112. Verbeek, D.S.; Knight, M.A.; Harmison, G.G.; Fischbeck, K.H.; Howell, B.W. Protein kinase C gamma mutations in spinocerebellar ataxia 14 increase kinase activity and alter membrane targeting. Brain 2005, 128 Pt 2, 436-442. [CrossRef]

113. Adachi, N.; Kobayashi, T.; Takahashi, H.; Kawasaki, T.; Shirai, Y.; Ueyama, T.; Matsuda, T.; Seki, T.; Sakai, N.; Saito, N. Enzymological analysis of mutant protein kinase Cgamma causing spinocerebellar ataxia type 14 and dysfunction in $\mathrm{Ca}^{2+}$ homeostasis. J. Biol. Chem. 2008, 283, 19854-19863. [CrossRef] [PubMed]

114. Moccia, F.; Lucariello, A.; Guerra, G. TRPC3-mediated Ca(2+) signals as a promising strategy to boost therapeutic angiogenesis in failing hearts: The role of autologous endothelial colony forming cells. J. Cell. Physiol. 2018, 233, 3901-3917. [CrossRef] [PubMed]

115. Verbeek, D.S.; Goedhart, J.; Bruinsma, L.; Sinke, R.J.; Reits, E.A. PKC gamma mutations in spinocerebellar ataxia type 14 affect $\mathrm{C} 1$ domain accessibility and kinase activity leading to aberrant MAPK signaling. J. Cell. Sci. 2008, 121 Pt 14, 2339-2349. [CrossRef]

116. Toulouse, A.; Nolan, Y.M. A role for mitogen-activated protein kinase phosphatase 1 (MKP1) in neural cell development and survival. Neural Regen. Res. 2015, 10, 1748-1749. [CrossRef]

117. Zhang, Y.; Snider, A.; Willard, L.; Takemoto, D.J.; Lin, D. Loss of Purkinje cells in the PKCgamma H101Y transgenic mouse. Biochem. Biophys. Res. Commun. 2009, 378, 524-528. [CrossRef]

118. Ji, J.; Hassler, M.L.; Shimobayashi, E.; Paka, N.; Streit, R.; Kapfhammer, J.P. Increased protein kinase C gamma activity induces Purkinje cell pathology in a mouse model of spinocerebellar ataxia 14. Neurobiol. Dis. 2014, 70, 1-11. [CrossRef]

119. Becker, E.B.E.; Oliver, P.L.; Glitsch, M.D.; Banks, G.T.; Achilli, F.; Hardy, A.; Nolan, P.M.; Fisher, E.M.C.; Davies, K.E. A point mutation in TRPC3 causes abnormal Purkinje cell development and cerebellar ataxia in moonwalker mice. Proc. Natl. Acad. Sci. USA 2009, 106, 6706-6711. [CrossRef]

120. Dulneva, A.; Lee, S.; Oliver, P.L.; Di Gleria, K.; Kessler, B.M.; Davies, K.E.; Becker, E.B. The mutant Moonwalker TRPC3 channel links calcium signaling to lipid metabolism in the developing cerebellum. Hum. Mol. Genet. 2015, 24, 4114-4125. [CrossRef]

121. Becker, E.B. The Moonwalker mouse: New insights into TRPC3 function, cerebellar development, and ataxia. Cerebellum 2014, 13, 628-636. [CrossRef] [PubMed]

122. Gees, M.; Colsoul, B.; Nilius, B. The role of transient receptor potential cation channels in $\mathrm{Ca}^{2+}$ signaling. Cold Spring Harb. Perspect. Biol. 2010, 2, a003962. [CrossRef] [PubMed]

123. Hartmann, J.; Konnerth, A. TRPC3-dependent synaptic transmission in central mammalian neurons. J. Mol. Med. 2015, 93, 983-989. [CrossRef] [PubMed] 
124. Kim, S.J. TRPC3 channel underlies cerebellar long-term depression. Cerebellum 2013, 12, 334-337. [CrossRef]

125. Becker, E.B.E. From mice to men: TRPC3 in cerebellar ataxia. Cerebellum 2017, 16, 877-879. [CrossRef]

126. Dragoni, S.; Laforenza, U.; Bonetti, E.; Lodola, F.; Bottino, C.; Guerra, G.; Borghesi, A.; Stronati, M.; Rosti, V.; Tanzi, F.; et al. Canonical transient receptor potential 3 channel triggers vascular endothelial growth factor-induced intracellular $\mathrm{Ca}^{2+}$ oscillations in endothelial progenitor cells isolated from umbilical cord blood. Stem Cells Dev. 2013, 22, 2561-2580. [CrossRef]

127. Moccia, F.; Negri, S.; Shekha, M.; Faris, P.; Guerra, G. Endothelial $\mathrm{Ca}^{2+}$ Signaling, Angiogenesis and Vasculogenesis: Just What It Takes to Make a Blood Vessel. Int. J. Mol. Sci. 2019, 20, 3962. [CrossRef]

128. Sekerková, G.; Kim, J.A.; Nigro, M.J.; Becker, E.B.E.; Hartmann, J.; Birnbaumer, L.; Mugnaini, E.; Martina, M. Early Onset of Ataxia in Moonwalker Mice Is Accompanied by Complete Ablation of Type II Unipolar Brush Cells and Purkinje Cell Dysfunction. J. Neurosci. 2013, 33, 19689-19694. [CrossRef]

129. Hartmann, J.; Dragicevic, E.; Adelsberger, H.; Henning, H.A.; Sumser, M.; Abramowitz, J.; Blum, R.; Dietrich, A.; Freichel, M.; Flockerzi, V.; et al. TRPC3 Channels Are Required for Synaptic Transmission and Motor Coordination. Neuron 2008, 59, 392-398. [CrossRef]

130. Huang, W.C.; Young, J.S.; Glitsch, M.D. Changes in TRPC channel expression during postnatal development of cerebellar neurons. Cell Calcium 2007, 42, 1-10. [CrossRef]

131. Negri, S.; Faris, P.; Pellavio, G.; Botta, L.; Orgiu, M.; Forcaia, G.; Sancini, G.; Laforenza, U.; Moccia, F. Group 1 metabotropic glutamate receptors trigger glutamate-induced intracellular $\mathrm{Ca}^{2+}$ signals and nitric oxide release in human brain microvascular endothelial cells. Cell. Mol. Life Sci. 2019, 1-19. [CrossRef] [PubMed]

132. Moccia, F.; Zuccolo, E.; Soda, T.; Tanzi, F.; Guerra, G.; Mapelli, L.; Lodola, F.; D’Angelo, E. Stim and Orai proteins in neuronal $\mathrm{Ca}^{2+}$ signaling and excitability. Front. Cell. Neurosci. 2015, 9, 153. [CrossRef] [PubMed]

133. Cheng, K.T.; Ong, H.L.; Liu, X.; Ambudkar, I.S. Contribution and Regulation of TRPC Channels in Store-Operated Ca ${ }^{2+}$ Entry. Curr. Top. Membr. 2013, 71, 149-179. [PubMed]

134. Lockwich, T.; Makusky, A.; Kowalak, J.; Markey, S.; Ambudkar, I. Proteomic analysis of TRPC channels. In TRP Channels; Zhu, M., Ed.; CRC Press: Boca Raton, FL, USA, 2011.

135. Spassova, M.A.; Soboloff, J.; He, L.P.; Xu, W.; Dziadek, M.A.; Gill, D.L. STIM1 has a plasma membrane role in the activation of store-operated $\mathrm{Ca}^{2+}$ channels. Proc. Natl. Acad. Sci. USA 2006, 103, 4040-4045. [CrossRef] [PubMed]

136. Soboloff, J.; Spassova, T.; Hewavitharana, L.; HE, L.; Luncsford, W.; Xu, K.; Venkatachalam, D.; van Rossum, R.; Patterson, D.; Gill, L. TRPC channels: Integrators of multiple cellular signals. In Transient Receptor Potential (TRP) Channels; Flockerzi, V., Nilius, B., Eds.; Springer: Berlin/Heidelberg, Germany, 2007; Volume 179, pp. 575-591.

137. Zhou, H.; Lin, Z.; Voges, K.; Ju, C.; Gao, Z.; Bosman, L.W.; Ruigrok, T.J.; Hoebeek, F.E.; De Zeeuw, C.I.; Schonewille, M. Cerebellar modules operate at different frequencies. eLife 2014, 3, e02536. [CrossRef] [PubMed]

138. Konur, S.; Ghosh, A. Calcium signaling and the control of dendritic development. Neuron 2005, 46, 401-405. [CrossRef] [PubMed]

139. Schrenk, K.; Kapfhammer, J.P.; Metzger, F. Altered dendritic development of cerebellar Purkinje cells in slice cultures from protein kinase Cgamma-deficient mice. Neuroscience 2002, 110, 675-689. [CrossRef]

140. Lopez-Bendito, G.; Shigemoto, R.; Lujan, R.; Juiz, J.M. Developmental changes in the localisation of the mGluR1alpha subtype of metabotropic glutamate receptors in Purkinje cells. Neuroscience 2001, 105, 413-429. [CrossRef]

141. Venkatachalam, K.; Zheng, F.; Gill, D.L. Regulation of canonical transient receptor potential (TRPC) channel function by diacylglycerol and protein kinase C. J. Biol. Chem. 2003, 278, 29031-29040. [CrossRef]

142. Trebak, M.; Hempel, N.; Wedel, B.J.; Smyth, J.T.; Bird, G.S.; Putney, J.W., Jr. Negative regulation of TRPC3 channels by protein kinase C-mediated phosphorylation of serine 712. Mol. Pharmacol. 2005, 67, 558-563. [CrossRef]

143. Glitsch, M.D. Activation of native TRPC3 cation channels by phospholipase D. FASEB J. 2010, 24, 318-325. [CrossRef] [PubMed]

144. Schmid, S.M.; Hollmann, M. To gate or not to gate: Are the delta subunits in the glutamate receptor family functional ion channels? Mol. Neurobiol. 2008, 37, 126-141. [CrossRef] [PubMed] 
145. Ady, V.; Perroy, J.; Tricoire, L.; Piochon, C.; Dadak, S.; Chen, X.; Dusart, I.; Fagni, L.; Lambolez, B.; Levenes, C. Type 1 metabotropic glutamate receptors (mGlu1) trigger the gating of GluD2 delta glutamate receptors. EMBO Rep. 2014, 15, 103-109. [CrossRef] [PubMed]

146. Kato, A.S.; Knierman, M.D.; Siuda, E.R.; Isaac, J.T.R.; Nisenbaum, E.S.; Bredt, D.S. Glutamate Receptor $\delta 2$ Associates with Metabotropic Glutamate Receptor 1 (mGluR1), Protein Kinase C $\gamma$, and Canonical Transient Receptor Potential 3 and Regulates mGluR1-Mediated Synaptic Transmission in Cerebellar Purkinje Neurons. J. Neurosci. 2012, 32, 15296-15308. [CrossRef] [PubMed]

147. Ingram, M.; Wozniak, E.A.L.; Duvick, L.; Yang, R.; Bergmann, P.; Carson, R.; O'Callaghan, B.; Zoghbi, H.Y.; Henzler, C.; Orr, H.T. Cerebellar Transcriptome Profiles of ATXN1 Transgenic Mice Reveal SCA1 Disease Progression and Protection Pathways. Neuron 2016, 89, 1194-1207. [CrossRef]

148. Lin, X.; Antalffy, B.; Kang, D.; Orr, H.T.; Zoghbi, H.Y. Polyglutamine expansion down-regulates specific neuronal genes before pathologic changes in SCA1. Nat. Neurosci. 2000, 3, 157-163. [CrossRef]

149. Pflieger, L.T.; Dansithong, W.; Paul, S.; Scoles, D.R.; Figueroa, K.P.; Meera, P.; Otis, T.S.; Facelli, J.C.; Pulst, S.M. Gene co-expression network analysis for identifying modules and functionally enriched pathways in SCA2. Hum. Mol. Genet. 2017, 26, 3069-3080. [CrossRef]

150. Fogel, B.; Hanson, S.; Becker, E. Mutation of the Murine Ataxia Gene TRPC3 Causes Cerebellar Ataxia in Humans (P1.009). Neurology 2016, 86, P1.009.

151. Fogel, B.L.; Hanson, S.M.; Becker, E.B.E. Do Mutations in the Murine Ataxia Gene TRPC3 Cause Cerebellar Ataxia in Humans? Mov. Disord. 2015, 30, 284-286. [CrossRef]

152. Becker, E.B.; Fogel, B.L.; Rajakulendran, S.; Dulneva, A.; Hanna, M.G.; Perlman, S.L.; Geschwind, D.H.; Davies, K.E. Candidate screening of the TRPC3 gene in cerebellar ataxia. Cerebellum 2011, 10, 296-299. [CrossRef]

153. Parys, J.B.; De Smedt, H. Inositol 1,4,5-trisphosphate and its receptors. Adv. Exp. Med. Biol. 2012, 740, $255-279$.

154. Foskett, J.K.; White, C.; Cheung, K.H.; Mak, D.O. Inositol trisphosphate receptor $\mathrm{Ca}^{2+}$ release channels. Physiol. Rev. 2007, 87, 593-658. [CrossRef] [PubMed]

155. Taylor, C.W.; Tovey, S.C. IP(3) receptors: Toward understanding their activation. Cold Spring Harb. Perspect. Biol. 2010, 2, a004010. [CrossRef] [PubMed]

156. Ivanova, H.; Vervliet, T.; Missiaen, L.; Parys, J.B.; De Smedt, H.; Bultynck, G. Inositol 1,4,5-trisphosphate receptor-isoform diversity in cell death and survival. Biochim. Biophys. Acta 2014, 1843, 2164-2183. [CrossRef] [PubMed]

157. Vermassen, E.; Parys, J.B.; Mauger, J.P. Subcellular distribution of the inositol 1,4,5-trisphosphate receptors: Functional relevance and molecular determinants. Biol. Cell 2004, 96, 3-17. [CrossRef]

158. Sharp, A.H.; Nucifora, F.C., Jr.; Blondel, O.; Sheppard, C.A.; Zhang, C.; Snyder, S.H.; Russell, J.T.; Ryugo, D.K.; Ross, C.A. Differential cellular expression of isoforms of inositol 1,4,5-triphosphate receptors in neurons and glia in brain. J. Comp. Neurol. 1999, 406, 207-220. [CrossRef]

159. Nakanishi, S.; Maeda, N.; Mikoshiba, K. Immunohistochemical localization of an inositol 1,4,5-trisphosphate receptor, P400, in neural tissue: Studies in developing and adult mouse brain. J. Neurosci. 1991, 11, 2075-2086. [CrossRef]

160. Yamada, N.; Makino, Y.; Clark, R.A.; Pearson, D.W.; Mattei, M.G.; Guenet, J.L.; Ohama, E.; Fujino, I.; Miyawaki, A.; Furuichi, T.; et al. Human inositol 1,4,5-trisphosphate type-1 receptor, InsP3R1: Structure, function, regulation of expression and chromosomal localization. Biochem. J. 1994, 302 Pt 3, 781-790. [CrossRef]

161. Bezprozvanny, I. Role of inositol 1,4,5-trisphosphate receptors in pathogenesis of Huntington's disease and spinocerebellar ataxias. Neurochem. Res. 2011, 36, 1186-1197. [CrossRef]

162. Berridge, M.J. Calcium signalling and Alzheimer's disease. Neurochem. Res. 2011, 36, 1149-1156. [CrossRef]

163. Synofzik, M.; Beetz, C.; Bauer, C.; Bonin, M.; Sanchez-Ferrero, E.; Schmitz-Hubsch, T.; Wullner, U.; Nagele, T.; Riess, O.; Schols, L.; et al. Spinocerebellar ataxia type 15: Diagnostic assessment, frequency, and phenotypic features. J. Med. Genet. 2011, 48, 407-412. [CrossRef] [PubMed]

164. Van de Leemput, J.; Chandran, J.; Knight, M.A.; Holtzclaw, L.A.; Scholz, S.; Cookson, M.R.; Houlden, H.; Gwinn-Hardy, K.; Fung, H.C.; Lin, X.; et al. Deletion at ITPR1 underlies ataxia in mice and spinocerebellar ataxia 15 in humans. PLoS Genet. 2007,3, e108. [CrossRef] [PubMed]

165. Storey, E.; Gardner, R.J.; Knight, M.A.; Kennerson, M.L.; Tuck, R.R.; Forrest, S.M.; Nicholson, G.A. A new autosomal dominant pure cerebellar ataxia. Neurology 2001, 57, 1913-1915. [CrossRef] [PubMed] 
166. Marelli, C.; van de Leemput, J.; Johnson, J.O.; Tison, F.; Thauvin-Robinet, C.; Picard, F.; Tranchant, C.; Hernandez, D.G.; Huttin, B.; Boulliat, J.; et al. SCA15 due to large ITPR1 deletions in a cohort of 333 Caucasian families with dominant ataxia. Arch. Neurol. 2011, 68, 637-643. [CrossRef] [PubMed]

167. Di Gregorio, E.; Orsi, L.; Godani, M.; Vaula, G.; Jensen, S.; Salmon, E.; Ferrari, G.; Squadrone, S.; Abete, M.C.; Cagnoli, C.; et al. Two Italian families with ITPR1 gene deletion presenting a broader phenotype of SCA15. Cerebellum 2010, 9, 115-123. [CrossRef]

168. Hara, K.; Shiga, A.; Nozaki, H.; Mitsui, J.; Takahashi, Y.; Ishiguro, H.; Yomono, H.; Kurisaki, H.; Goto, J.; Ikeuchi, T.; et al. Total deletion and a missense mutation of ITPR1 in Japanese SCA15 families. Neurology 2008, 71, 547-551. [CrossRef]

169. Iwaki, A.; Kawano, Y.; Miura, S.; Shibata, H.; Matsuse, D.; Li, W.; Furuya, H.; Ohyagi, Y.; Taniwaki, T.; Kira, J.; et al. Heterozygous deletion of ITPR1, but not SUMF1, in spinocerebellar ataxia type 16. J. Med. Genet. 2008, 45, 32-35. [CrossRef]

170. Gardner, R.J. “SCA16" is really SCA15. J. Med. Genet. 2008, 45, 192. [CrossRef]

171. Zambonin, J.L.; Bellomo, A.; Ben-Pazi, H.; Everman, D.B.; Frazer, L.M.; Geraghty, M.T.; Harper, A.D.; Jones, J.R.; Kamien, B.; Kernohan, K.; et al. Spinocerebellar ataxia type 29 due to mutations in ITPR1: A case series and review of this emerging congenital ataxia. Orphanet J. Rare Dis. 2017, 12, 121. [CrossRef]

172. Huang, L.; Chardon, J.W.; Carter, M.T.; Friend, K.L.; Dudding, T.E.; Schwartzentruber, J.; Zou, R.; Schofield, P.W.; Douglas, S.; Bulman, D.E.; et al. Missense mutations in ITPR1 cause autosomal dominant congenital nonprogressive spinocerebellar ataxia. Orphanet J. Rare Dis. 2012, 7, 67. [CrossRef]

173. Hirota, J.; Ando, H.; Hamada, K.; Mikoshiba, K. Carbonic anhydrase-related protein is a novel binding protein for inositol 1,4,5-trisphosphate receptor type 1. Biochem. J. 2003, 372, 435-441. [CrossRef] [PubMed]

174. Kerkhofs, M.; Seitaj, B.; Ivanova, H.; Monaco, G.; Bultynck, G.; Parys, J.B. Pathophysiological consequences of isoform-specific IP3 receptor mutations. Biochim. Biophys. Acta Mol. Cell Res. 2018, 1865, 1707-1717. [CrossRef] [PubMed]

175. Street, V.A.; Bosma, M.M.; Demas, V.P.; Regan, M.R.; Lin, D.D.; Robinson, L.C.; Agnew, W.S.; Tempel, B.L. The type 1 inositol 1,4,5-trisphosphate receptor gene is altered in the opisthotonos mouse. J. Neurosci. 1997, 17, 635-645. [CrossRef] [PubMed]

176. Patterson, R.L.; Boehning, D.; Snyder, S.H. Inositol 1,4,5-trisphosphate receptors as signal integrators. Annu. Rev. Biochem. 2004, 73, 437-465. [CrossRef] [PubMed]

177. Tu, H.; Miyakawa, T.; Wang, Z.; Glouchankova, L.; Iino, M.; Bezprozvanny, I. Functional characterization of the type 1 inositol 1,4,5-trisphosphate receptor coupling domain SII(+/-) splice variants and the Opisthotonos mutant form. Biophys. J. 2002, 82, 1995-2004. [CrossRef]

178. Matsumoto, M.; Nakagawa, T.; Inoue, T.; Nagata, E.; Tanaka, K.; Takano, H.; Minowa, O.; Kuno, J.; Sakakibara, S.; Yamada, M.; et al. Ataxia and epileptic seizures in mice lacking type 1 inositol 1,4,5-trisphosphate receptor. Nature 1996, 379, 168-171. [CrossRef]

179. Matsumoto, M.; Nagata, E. Type 1 inositol 1,4,5-trisphosphate receptor knock-out mice: Their phenotypes and their meaning in neuroscience and clinical practice. J. Mol. Med. 1999, 77, 406-411. [CrossRef]

180. Inoue, T.; Kato, K.; Kohda, K.; Mikoshiba, K. Type 1 inositol 1,4,5-trisphosphate receptor is required for induction of long-term depression in cerebellar Purkinje neurons. J. Neurosci. 1998, 18, 5366-5373. [CrossRef]

181. Hisatsune, C.; Miyamoto, H.; Hirono, M.; Yamaguchi, N.; Sugawara, T.; Ogawa, N.; Ebisui, E.; Ohshima, T.; Yamada, M.; Hensch, T.K.; et al. IP3R1 deficiency in the cerebellum/brainstem causes basal ganglia-independent dystonia by triggering tonic Purkinje cell firings in mice. Front. Neural Circuits 2013, 7, 156. [CrossRef]

182. Klar, J.; Ali, Z.; Farooq, M.; Khan, K.; Wikström, J.; Iqbal, M.; Zulfiqar, S.; Faryal, S.; Baig, S.M.; Dahl, N. A missense variant in ITPR1 provides evidence for autosomal recessive SCA29 with asymptomatic cerebellar hypoplasia in carriers. Eur. J. Hum. Genet. 2017, 25, 848-853. [CrossRef]

183. Kawaguchi, Y.; Okamoto, T.; Taniwaki, M.; Aizawa, M.; Inoue, M.; Katayama, S.; Kawakami, H.; Nakamura, S.; Nishimura, M.; Akiguchi, I.; et al. CAG expansions in a novel gene for Machado-Joseph disease at chromosome 14q32.1. Nat. Genet. 1994, 8, 221-228. [CrossRef] [PubMed]

184. Imbert, G.; Saudou, F.; Yvert, G.; Devys, D.; Trottier, Y.; Garnier, J.M.; Weber, C.; Mandel, J.L.; Cancel, G.; Abbas, N.; et al. Cloning of the gene for spinocerebellar ataxia 2 reveals a locus with high sensitivity to expanded CAG/glutamine repeats. Nat. Genet. 1996, 14, 285-291. [CrossRef] [PubMed] 
185. Pulst, S.M.; Nechiporuk, A.; Nechiporuk, T.; Gispert, S.; Chen, X.N.; Lopes-Cendes, I.; Pearlman, S.; Starkman, S.; Orozco-Diaz, G.; Lunkes, A.; et al. Moderate expansion of a normally biallelic trinucleotide repeat in spinocerebellar ataxia type 2. Nat. Genet. 1996, 14, 269-276. [CrossRef] [PubMed]

186. Sanpei, K.; Takano, H.; Igarashi, S.; Sato, T.; Oyake, M.; Sasaki, H.; Wakisaka, A.; Tashiro, K.; Ishida, Y.; Ikeuchi, T.; et al. Identification of the spinocerebellar ataxia type 2 gene using a direct identification of repeat expansion and cloning technique, DIRECT. Nat. Genet. 1996, 14, 277-284. [CrossRef]

187. Paulson, H.L.; Das, S.S.; Crino, P.B.; Perez, M.K.; Patel, S.C.; Gotsdiner, D.; Fischbeck, K.H.; Pittman, R.N. Machado-Joseph disease gene product is a cytoplasmic protein widely expressed in brain. Ann. Neurol. 1997, 41, 453-462. [CrossRef]

188. Trottier, Y.; Cancel, G.; An-Gourfinkel, I.; Lutz, Y.; Weber, C.; Brice, A.; Hirsch, E.; Mandel, J.L. Heterogeneous intracellular localization and expression of ataxin-3. Neurobiol. Dis. 1998, 5, 335-347. [CrossRef]

189. Huynh, D.P.; Figueroa, K.; Hoang, N.; Pulst, S.M. Nuclear localization or inclusion body formation of ataxin-2 are not necessary for SCA2 pathogenesis in mouse or human. Nat. Genet. 2000, 26, 44-50. [CrossRef]

190. Schols, L.; Bauer, P.; Schmidt, T.; Schulte, T.; Riess, O. Autosomal dominant cerebellar ataxias: Clinical features, genetics, and pathogenesis. Lancet Neurol. 2004, 3, 291-304. [CrossRef]

191. Lastres-Becker, I.; Rub, U.; Auburger, G. Spinocerebellar ataxia 2 (SCA2). Cerebellum 2008, 7, $115-124$. [CrossRef]

192. Koeppen, A.H. The Neuropathology of Spinocerebellar Ataxia Type 3/Machado-Joseph Disease. Adv. Exp. Med. Biol. 2018, 1049, 233-241.

193. Coutinho, P.; Andrade, C. Autosomal dominant system degeneration in Portuguese families of the Azores Islands. A new genetic disorder involving cerebellar, pyramidal, extrapyramidal and spinal cord motor functions. Neurology 1978, 28, 703-709. [CrossRef] [PubMed]

194. Pulst, S.M.; Santos, N.; Wang, D.; Yang, H.; Huynh, D.; Velazquez, L.; Figueroa, K.P. Spinocerebellar ataxia type 2: PolyQ repeat variation in the CACNA1A calcium channel modifies age of onset. Brain 2005, 128 Pt 10, 2297-2303. [CrossRef]

195. Kiehl, T.R.; Nechiporuk, A.; Figueroa, K.P.; Keating, M.T.; Huynh, D.P.; Pulst, S.M. Generation and characterization of Sca2 (ataxin-2) knockout mice. Biochem. Biophys. Res. Commun. 2006, 339, 17-24. [CrossRef] [PubMed]

196. Egorova, P.A.; Zakharova, O.A.; Vlasova, O.L.; Bezprozvanny, I.B. In vivo analysis of cerebellar Purkinje cell activity in SCA2 transgenic mouse model. J. Neurophysiol. 2016, 115, 2840-2851. [CrossRef] [PubMed]

197. Kasumu, A.W.; Liang, X.; Egorova, P.; Vorontsova, D.; Bezprozvanny, I. Chronic suppression of inositol 1,4,5-triphosphate receptor-mediated calcium signaling in cerebellar purkinje cells alleviates pathological phenotype in spinocerebellar ataxia 2 mice. J. Neurosci. 2012, 32, 12786-12796. [CrossRef] [PubMed]

198. Edgerton, J.R.; Reinhart, P.H. Distinct contributions of small and large conductance $\mathrm{Ca}^{2+}$-activated $\mathrm{K}^{+}$ channels to rat Purkinje neuron function. J. Physiol. 2003, 548 Pt 1, 53-69. [CrossRef]

199. Womack, M.D.; Khodakhah, K. Somatic and dendritic small-conductance calcium-activated potassium channels regulate the output of cerebellar Purkinje neurons. J. Neurosci. 2003, 23, 2600-2607. [CrossRef]

200. Kasumu, A.W.; Hougaard, C.; Rode, F.; Jacobsen, T.A.; Sabatier, J.M.; Eriksen, B.L.; Strobaek, D.; Liang, X.; Egorova, P.; Vorontsova, D.; et al. Selective positive modulator of calcium-activated potassium channels exerts beneficial effects in a mouse model of spinocerebellar ataxia type 2. Chem. Biol. 2012, 19, 1340-1353. [CrossRef]

201. Huynh, D.P.; Del Bigio, M.R.; Ho, D.H.; Pulst, S.M. Expression of ataxin-2 in brains from normal individuals and patients with Alzheimer's disease and spinocerebellar ataxia 2. Ann. Neurol. 1999, 45, 232-241. [CrossRef]

202. La Spada, A.R.; Taylor, J.P. Repeat expansion disease: Progress and puzzles in disease pathogenesis. Nat. Rev. Genet. 2010, 11, 247-258. [CrossRef]

203. Bauer, P.O.; Nukina, N. The pathogenic mechanisms of polyglutamine diseases and current therapeutic strategies. J. Neurochem. 2009, 110, 1737-1765. [CrossRef] [PubMed]

204. Chen, X.; Tang, T.S.; Tu, H.; Nelson, O.; Pook, M.; Hammer, R.; Nukina, N.; Bezprozvanny, I. Deranged calcium signaling and neurodegeneration in spinocerebellar ataxia type 3. J. Neurosci. 2008, 28, 12713-12724. [CrossRef] [PubMed]

205. Haacke, A.; Hartl, F.U.; Breuer, P. Calpain inhibition is sufficient to suppress aggregation of polyglutamine-expanded ataxin-3. J. Biol. Chem. 2007, 282, 18851-18856. [CrossRef] [PubMed] 
206. Chou, A.H.; Yeh, T.H.; Ouyang, P.; Chen, Y.L.; Chen, S.Y.; Wang, H.L. Polyglutamine-expanded ataxin-3 causes cerebellar dysfunction of SCA3 transgenic mice by inducing transcriptional dysregulation. Neurobiol. Dis. 2008, 31, 89-101. [CrossRef]

207. Zoghbi, H.Y.; Orr, H.T. Spinocerebellar ataxia type 1. Semin. Cell Biol. 1995, 6, 29-35. [CrossRef]

208. Orr, H.T.; Chung, M.Y.; Banfi, S.; Kwiatkowski, T.J., Jr.; Servadio, A.; Beaudet, A.L.; McCall, A.E.; Duvick, L.A.; Ranum, L.P.; Zoghbi, H.Y. Expansion of an unstable trinucleotide CAG repeat in spinocerebellar ataxia type 1. Nat. Genet. 1993, 4, 221-226. [CrossRef]

209. Banfi, S.; Servadio, A.; Chung, M.Y.; Kwiatkowski, T.J., Jr.; McCall, A.E.; Duvick, L.A.; Shen, Y.; Roth, E.J.; Orr, H.T.; Zoghbi, H.Y. Identification and characterization of the gene causing type 1 spinocerebellar ataxia. Nat. Genet. 1994, 7, 513-520. [CrossRef]

210. Gusella, J.F.; MacDonald, M.E. Molecular genetics: Unmasking polyglutamine triggers in neurodegenerative disease. Nat. Rev. Neurosci. 2000, 1, 109-115. [CrossRef]

211. Matilla-Duenas, A.; Goold, R.; Giunti, P. Clinical, genetic, molecular, and pathophysiological insights into spinocerebellar ataxia type 1. Cerebellum 2008, 7, 106-114. [CrossRef]

212. Servadio, A.; Koshy, B.; Armstrong, D.; Antalffy, B.; Orr, H.T.; Zoghbi, H.Y. Expression analysis of the ataxin-1 protein in tissues from normal and spinocerebellar ataxia type 1 individuals. Nat. Genet. 1995, 10, 94-98. [CrossRef]

213. Durr, A. Autosomal dominant cerebellar ataxias: Polyglutamine expansions and beyond. Lancet Neurol. 2010, 9, 885-894. [CrossRef]

214. Seidel, K.; Siswanto, S.; Brunt, E.R.; den Dunnen, W.; Korf, H.W.; Rub, U. Brain pathology of spinocerebellar ataxias. Acta Neuropathol. 2012, 124, 1-21. [CrossRef] [PubMed]

215. Koeppen, A.H.; Ramirez, R.L.; Bjork, S.T.; Bauer, P.; Feustel, P.J. The reciprocal cerebellar circuitry in human hereditary ataxia. Cerebellum 2013, 12, 493-503. [CrossRef] [PubMed]

216. Robitaille, Y.; Schut, L.; Kish, S.J. Structural and immunocytochemical features of olivopontocerebellar atrophy caused by the spinocerebellar ataxia type 1 (SCA-1) mutation define a unique phenotype. Acta Neuropathol. 1995, 90, 572-581. [CrossRef]

217. Skinner, P.J.; Koshy, B.T.; Cummings, C.J.; Klement, I.A.; Helin, K.; Servadio, A.; Zoghbi, H.Y.; Orr, H.T. Ataxin-1 with an expanded glutamine tract alters nuclear matrix-associated structures. Nature 1997, 389, 971-974. [CrossRef]

218. Duyckaerts, C.; Durr, A.; Cancel, G.; Brice, A. Nuclear inclusions in spinocerebellar ataxia type 1. Acta Neuropathol. 1999, 97, 201-207. [CrossRef]

219. Hendelman, W.J.; Aggerwal, A.S. The Purkinje neuron: I. A Golgi study of its development in the mouse and in culture. J. Comp. Neurol. 1980, 193, 1063-1079. [CrossRef]

220. Banfi, S.; Servadio, A.; Chung, M.; Capozzoli, F.; Duvick, L.A.; Elde, R.; Zoghbi, H.Y.; Orr, H.T. Cloning and developmental expression analysis of the murine homolog of the spinocerebellar ataxia type 1 gene (Sca1). Hum. Mol. Genet. 1996, 5, 33-40. [CrossRef]

221. Matilla, A.; Roberson, E.D.; Banfi, S.; Morales, J.; Armstrong, D.L.; Burright, E.N.; Orr, H.T.; Sweatt, J.D.; Zoghbi, H.Y.; Matzuk, M.M. Mice lacking ataxin-1 display learning deficits and decreased hippocampal paired-pulse facilitation. J. Neurosci. 1998, 18, 5508-5516. [CrossRef]

222. Burright, E.N.; Clark, H.B.; Servadio, A.; Matilla, T.; Feddersen, R.M.; Yunis, W.S.; Duvick, L.A.; Zoghbi, H.Y.; Orr, H.T. SCA1 transgenic mice: A model for neurodegeneration caused by an expanded CAG trinucleotide repeat. Cell 1995, 82, 937-948. [CrossRef]

223. Clark, H.B.; Burright, E.N.; Yunis, W.S.; Larson, S.; Wilcox, C.; Hartman, B.; Matilla, A.; Zoghbi, H.Y.; Orr, H.T. Purkinje cell expression of a mutant allele of SCA1 in transgenic mice leads to disparate effects on motor behaviors, followed by a progressive cerebellar dysfunction and histological alterations. J. Neurosci. 1997, 17, 7385-7395. [CrossRef]

224. Clark, H.B.; Orr, H.T. Spinocerebellar ataxia type 1-Modeling the pathogenesis of a polyglutamine neurodegenerative disorder in transgenic mice. J. Neuropathol. Exp. Neurol. 2000, 59, 265-270. [CrossRef]

225. Barnes, J.A.; Ebner, B.A.; Duvick, L.A.; Gao, W.; Chen, G.; Orr, H.T.; Ebner, T.J. Abnormalities in the Climbing Fiber-Purkinje Cell Circuitry Contribute to Neuronal Dysfunction in ATXN1[82Q] Mice. J. Neurosci. 2011, 31, 12778-12789. [CrossRef] [PubMed] 
226. Vig, P.J.; Subramony, S.H.; Burright, E.N.; Fratkin, J.D.; McDaniel, D.O.; Desaiah, D.; Qin, Z. Reduced immunoreactivity to calcium-binding proteins in Purkinje cells precedes onset of ataxia in spinocerebellar ataxia-1 transgenic mice. Neurology 1998, 50, 106-113. [CrossRef] [PubMed]

227. Vig, P.J.; Subramony, S.H.; McDaniel, D.O. Calcium homeostasis and spinocerebellar ataxia-1 (SCA-1). Brain Res. Bull. 2001, 56, 221-225. [CrossRef]

228. Rossi, P.I.; Vaccari, C.M.; Terracciano, A.; Doria-Lamba, L.; Facchinetti, S.; Priolo, M.; Ayuso, C.; De Jorge, L.; Gimelli, S.; Santorelli, F.M.; et al. The metabotropic glutamate receptor 1, GRM1: Evaluation as a candidate gene for inherited forms of cerebellar ataxia. J. Neurol. 2010, 257, 598-602. [CrossRef] [PubMed]

229. Guergueltcheva, V.; Azmanov, D.N.; Angelicheva, D.; Smith, K.R.; Chamova, T.; Florez, L.; Bynevelt, M.; Nguyen, T.; Cherninkova, S.; Bojinova, V.; et al. Autosomal-recessive congenital cerebellar ataxia is caused by mutations in metabotropic glutamate receptor 1. Am. J. Hum. Genet. 2012, 91, 553-564. [CrossRef]

230. Watson, L.M.; Bamber, E.; Schnekenberg, R.P.; Williams, J.; Bettencourt, C.; Lickiss, J.; Jayawant, S.; Fawcett, K.; Clokie, S.; Wallis, Y.; et al. Dominant Mutations in GRM1 Cause Spinocerebellar Ataxia Type 44. Am. J. Hum. Genet. 2017, 101, 451-458. [CrossRef]

231. Zu, T.; Duvick, L.A.; Kaytor, M.D.; Berlinger, M.S.; Zoghbi, H.Y.; Clark, H.B.; Orr, H.T. Recovery from polyglutamine-induced neurodegeneration in conditional SCA1 transgenic mice. J. Neurosci. 2004, 24, 8853-8861. [CrossRef]

232. Shuvaev, A.N.; Hosoi, N.; Sato, Y.; Yanagihara, D.; Hirai, H. Progressive impairment of cerebellar mGluR signalling and its therapeutic potential for cerebellar ataxia in spinocerebellar ataxia type 1 model mice. J. Physiol. 2017, 595, 141-164. [CrossRef]

233. Hoxha, E.; Balbo, I.; Miniaci, M.C.; Tempia, F. Purkinje Cell Signaling Deficits in Animal Models of Ataxia. Front. Synaptic Neurosci. 2018, 10, 6. [CrossRef] [PubMed]

234. Konno, A.; Shuvaev, A.N.; Miyake, N.; Miyake, K.; Iizuka, A.; Matsuura, S.; Huda, F.; Nakamura, K.; Yanagi, S.; Shimada, T.; et al. Mutant ataxin-3 with an abnormally expanded polyglutamine chain disrupts dendritic development and metabotropic glutamate receptor signaling in mouse cerebellar Purkinje cells. Cerebellum 2014, 13, 29-41. [CrossRef] [PubMed]

235. Hansen, S.T.; Meera, P.; Otis, T.S.; Pulst, S.M. Changes in Purkinje cell firing and gene expression precede behavioral pathology in a mouse model of SCA2. Hum. Mol. Genet. 2013, 22, 271-283. [CrossRef]

236. Meera, P.; Pulst, S.; Otis, T. A positive feedback loop linking enhanced mGluR function and basal calcium in spinocerebellar ataxia type 2. Elife 2017, 6, e26377. [CrossRef]

237. Bezprozvanny, I.; Klockgether, T. Therapeutic prospects for spinocerebellar ataxia type 2 and 3. Drugs Future 2009, 34. [CrossRef]

238. Kimura, T.; Sugimori, M.; Llinas, R.R. Purkinje cell long-term depression is prevented by T-588, a neuroprotective compound that reduces cytosolic calcium release from intracellular stores. Proc. Natl. Acad. Sci. USA 2005, 102, 17160-17165. [CrossRef]

239. Goncalves, N.; Simoes, A.T.; Prediger, R.D.; Hirai, H.; Cunha, R.A.; Pereira de Almeida, L. Caffeine alleviates progressive motor deficits in a transgenic mouse model of spinocerebellar ataxia. Ann. Neurol. 2017, 81, 407-418. [CrossRef]

240. Ristori, G.; Romano, S.; Visconti, A.; Cannoni, S.; Spadaro, M.; Frontali, M.; Pontieri, F.E.; Vanacore, N.; Salvetti, M. Riluzole in cerebellar ataxia: A randomized, double-blind, placebo-controlled pilot trial. Neurology 2010, 74, 839-845. [CrossRef]

241. Keiser, M.S.; Kordasiewicz, H.B.; McBride, J.L. Gene suppression strategies for dominantly inherited neurodegenerative diseases: Lessons from Huntington's disease and spinocerebellar ataxia. Hum. Mol. Genet. 2016, 25, R53-R64. [CrossRef]

242. Persengiev, S.; Kondova, I.; Otting, N.; Koeppen, A.H.; Bontrop, R.E. Genome-wide analysis of miRNA expression reveals a potential role for miR-144 in brain aging and spinocerebellar ataxia pathogenesis. Neurobiol. Aging 2011, 32, 2316.e17-2316.e27. [CrossRef]

243. Xia, H.; Mao, Q.; Eliason, S.L.; Harper, S.Q.; Martins, I.H.; Orr, H.T.; Paulson, H.L.; Yang, L.; Kotin, R.M.; Davidson, B.L. RNAi suppresses polyglutamine-induced neurodegeneration in a model of spinocerebellar ataxia. Nat. Med. 2004, 10, 816-820. [CrossRef] [PubMed]

244. Scoles, D.R.; Meera, P.; Schneider, M.D.; Paul, S.; Dansithong, W.; Figueroa, K.P.; Hung, G.; Rigo, F.; Bennett, C.F.; Otis, T.S.; et al. Antisense oligonucleotide therapy for spinocerebellar ataxia type 2. Nature 2017, 544, 362-366. [CrossRef] [PubMed] 
245. McLoughlin, H.S.; Moore, L.R.; Chopra, R.; Komlo, R.; McKenzie, M.; Blumenstein, K.G.; Zhao, H.; Kordasiewicz, H.B.; Shakkottai, V.G.; Paulson, H.L. Oligonucleotide therapy mitigates disease in spinocerebellar ataxia type 3 mice. Ann. Neurol. 2018, 84, 64-77. [CrossRef] [PubMed]

246. Kaemmerer, W.F.; Low, W.C. Cerebellar allografts survive and transiently alleviate ataxia in a transgenic model of spinocerebellar ataxia type-1. Exp. Neurol. 1999, 158, 301-311. [CrossRef]

247. Chintawar, S.; Hourez, R.; Ravella, A.; Gall, D.; Orduz, D.; Rai, M.; Bishop, D.P.; Geuna, S.; Schiffmann, S.N.; Pandolfo, M. Grafting neural precursor cells promotes functional recovery in an SCA1 mouse model. J. Neurosci. 2009, 29, 13126-13135. [CrossRef]

248. Mendonca, L.S.; Nobrega, C.; Hirai, H.; Kaspar, B.K.; Pereira de Almeida, L. Transplantation of cerebellar neural stem cells improves motor coordination and neuropathology in Machado-Joseph disease mice. Brain 2015, 138 Pt 2, 320-335. [CrossRef]

249. Chang, Y.K.; Chen, M.H.; Chiang, Y.H.; Chen, Y.F.; Ma, W.H.; Tseng, C.Y.; Soong, B.W.; Ho, J.H.; Lee, O.K. Mesenchymal stem cell transplantation ameliorates motor function deterioration of spinocerebellar ataxia by rescuing cerebellar Purkinje cells. J. Biomed. Sci. 2011, 18, 54. [CrossRef]

250. Takahashi, K.; Yamanaka, S. Induction of pluripotent stem cells from mouse embryonic and adult fibroblast cultures by defined factors. Cell 2006, 126, 663-676. [CrossRef]

251. Takahashi, K.; Tanabe, K.; Ohnuki, M.; Narita, M.; Ichisaka, T.; Tomoda, K.; Yamanaka, S. Induction of pluripotent stem cells from adult human fibroblasts by defined factors. Cell 2007, 131, 861-872. [CrossRef]

252. Buijsen, R.A.M.; Gardiner, S.L.; Bouma, M.J.; van der Graaf, L.M.; Boogaard, M.W.; Pepers, B.A.; Eussen, B.; de Klein, A.; Freund, C.; van Roon-Mom, W.M.C. Generation of 3 spinocerebellar ataxia type 1 (SCA1) patient-derived induced pluripotent stem cell lines LUMCi002-A, B, and C and 2 unaffected sibling control induced pluripotent stem cell lines LUMCi003-A and B. Stem Cell Res. 2018, 29, 125-128. [CrossRef]

253. Ishida, Y.; Kawakami, H.; Kitajima, H.; Nishiyama, A.; Sasai, Y.; Inoue, H.; Muguruma, K. Vulnerability of Purkinje Cells Generated from Spinocerebellar Ataxia Type 6 Patient-Derived iPSCs. Cell Rep. 2016, 17, 1482-1490. [CrossRef]

254. Tian, Z.M.; Chen, T.; Zhong, N.; Li, Z.C.; Yin, F.; Liu, S. Clinical study of transplantation of neural stem cells in therapy of inherited cerebellar atrophy. J. Peking Univ. Health Sci. 2009, 41, 456-458.

255. Lee, P.H.; Lee, J.E.; Kim, H.S.; Song, S.K.; Lee, H.S.; Nam, H.S.; Cheong, J.W.; Jeong, Y.; Park, H.J.; Kim, D.J.; et al. A randomized trial of mesenchymal stem cells in multiple system atrophy. Ann. Neurol. 2012, 72, 32-40. [CrossRef]

256. Duenas, A.M.; Goold, R.; Giunti, P. Molecular pathogenesis of spinocerebellar ataxias. Brain 2006, 129, 1357-1370. [CrossRef]

(C) 2019 by the authors. Licensee MDPI, Basel, Switzerland. This article is an open access article distributed under the terms and conditions of the Creative Commons Attribution (CC BY) license (http://creativecommons.org/licenses/by/4.0/). 